\title{
Financial System Structure in Colombia: A Proposal for a Reform Agenda
}

\author{
by
}

\section{JAVIER DE LA CRUZ AND CONSTANTINOS STEPHANOU*}

\begin{abstract}
The objective of this policy paper is to identify and propose high-level legal and regulatory reforms to Colombia's financial system structure that would enhance efficiency and/or mitigate risks. Five specific and four general reforms are proposed and evaluated based on their compatibility with the aforementioned objectives, ease of implementation, impact, and consistency with international practice. Potential implications for supervision and competition, as well as likely criteria for developing a carefully sequenced reform roadmap, are also highlighted.
\end{abstract}

\section{JEL Classification Code:}

Keywords: Colombia, financial structure, financial system, financial conglomerates, consolidated supervision.

World Bank Policy Research Working Paper 4006, September 2006

The Policy Research Working Paper Series disseminates the findings of work in progress to encourage the exchange of ideas about development issues. An objective of the series is to get the findings out quickly, even if the presentations are less than fully polished. The papers carry the names of the authors and should be cited accordingly. The findings, interpretations, and conclusions expressed in this paper are entirely those of the authors. They do not necessarily represent the view of the World Bank, its Executive Directors, or the countries they represent. Policy Research Working Papers are available online at http://econ.worldbank.org.

\footnotetext{
* Javier de la Cruz is a consultant (formerly with the Bank of Spain) and Constantinos A. Stephanou (cstephanou@worldbank.org) is a Financial Economist in the World Bank's Latin America and the Caribbean Region. The authors would like to thank the Colombian authorities for their excellent cooperation, and express their gratitude to Brian Quinn, Pascual O’Dogherty, Augusto de la Torre, Giovanni Majnoni and others for helpful comments and suggestions.
} 


\section{Table of Contents}

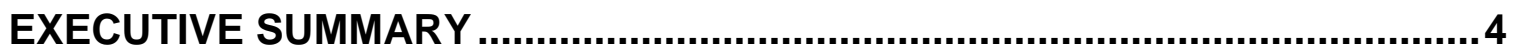

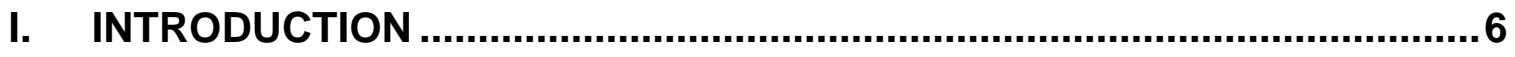

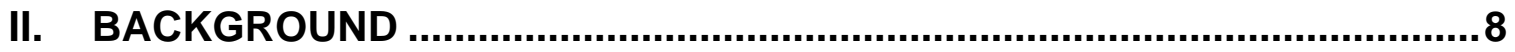

A. Evolution of legal and regulatory framework .......................................................... 8

B. Market characteristics and recent developments........................................................ 10

III. ANALYTICAL APPROACH AND PROPOSED REFORMS ..................18

A. Analytical Approach ……………………………............................................. 18

B. Specific Reform 1: Financial Leasing .................................................................... 19

C. Specific Reform 2: Collective Investment Schemes ................................................ 21

D. Specific Reform 3: Fiduciary Activities ............................................................. 24

E. Specific Reform 4: Investment Banking - Banks, CFs and Comisionistas de Bolsa26

F. Specific Reform 5: Sociedades de Capitalización .................................................... 30

G. General Reform 1: Legal Framework ..................................................................... 31

H. General Reform 2: Prevention of Conflicts of Interest............................................ 33

I. General Reform 3: Financial System 'Perimeter' ………........................................... 35

J. General Reform 4: Financial Conglomerates ............................................................... 37

IV. CONCLUSIONS AND PROPOSED ROADMAP …...............................41

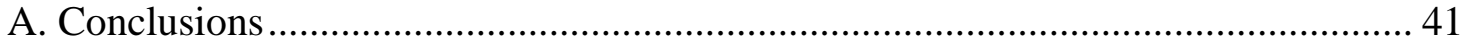

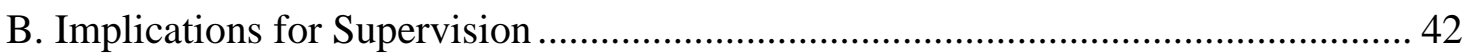

C. Implications for Competition .............................................................................. 43

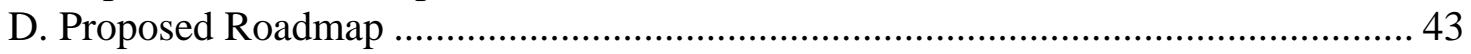

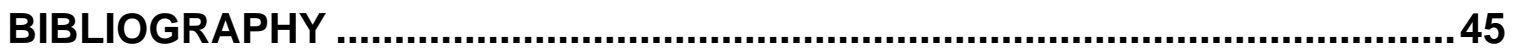




\section{List of Tables}

Table 1: Main Legal Reforms to Financial System Structure (1990-2005)......................... 9

Table 2: Number of Financial Institutions (1995-2005) .................................................. 11

Table 3: Financial Performance of Credit Institutions (1998-2005)................................. 12

Table 4: Comparative Performance of Financial Systems in Selected Countries (latest

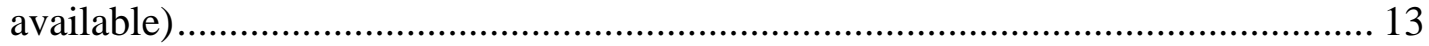

Table 5: Five Largest Firms by Market Segment (2005)................................................. 14

Table 6: Entities Controlled by Largest Financial Conglomerates (latest available) ....... 14

Table 7: Classification of Financial Conglomerates (latest available) ............................. 15

Table 8: Size and Ownership of Five Largest Leasing CFCs (December 2005)............... 21

Table 9: Types of Collective Investment Schemes by Provider ........................................ 21

Table 10: Size and Ownership of Five Largest Collective Investment Scheme Providers

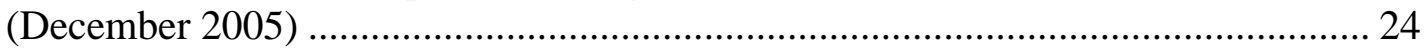

Table 11: Size and Ownership of Five Largest Fiduciarias Excluding Investments (December 2005) ……………………………………..................................... 26

Table 12: Permissible Investment Banking Activities in Chile, Mexico and Spain......... 27

Table 13: Size and Ownership of Corporaciones Financieras (February 2006) ............... 29

Table 14: Size and Ownership of Five Largest Comisionistas (2005) ............................. 29

Table 15: Size and Ownership of Sociedades de Capitalización (December 2005).......... 31

Table 16: Summary of Proposed Recommendations......................................................... 41

\section{List of Figures}

Figure 1: Composition of Financial System Assets (1995-2005)...................................... 11

Figure 2: Conglomeration by Type of Financial Entity (latest available) ……………...... 15

Figure 3: Collective Investment Scheme Providers (December 2005)............................. 22

Figure 4: Size of Mutual Fund Industry in Selected Countries (2004)............................. 22

Figure 5: Evolution of Fiduciarias by Asset Type (1996-2005) ....................................... 25

Figure 6: Stylized Structure of Domestic Mixed-Activity Conglomerate ......................... 39 


\section{Executive Summary}

The objective of this policy paper is to identify and propose high-level legal and regulatory reforms to the financial system structure that would enhance efficiency and/or mitigate risks by:

- removing unnecessary regulatory barriers or filling in existing gaps in order to let market forces determine the most appropriate financial structure

- clarifying, completing and ensuring consistency in the prudential framework. The paper does not cover all dimensions of the financial system structure and, given tight time constraints and fine-tuning considerations that are beyond the scope of this exercise, does not provide an in-depth analysis of each reform proposal.

The Colombian financial system had historically developed under a model of specialized 'vehicles' subject to severe restrictions on permissible activities, especially for deposit-taking institutions. Law 45/1990 converted the system into one of "multibanking” (matrix-subsidiaries) and promoted the creation of financial conglomerates. Legal reforms during the last fifteen years have provided more flexibility but have not fundamentally changed the overall picture. However, the current model is already de facto close to universal banking because of the presence of financial conglomerates, although it is more inefficient because their structures are not fully market-determined. This has historically led to the duplication of resources, operational inefficiencies and lower economies of scale, while 'isolation' has also inhibited cross-selling efforts across group companies.

The number of financial institutions has declined, while the relative importance of institutional investors and capital markets has increased, over the last 10 years. The banking sector has mostly recovered from the 1999 crisis, although financial intermediation has been slow to pick up. Colombia's financial system is dominated by financial conglomerates, the most important of which belong to domestic mixed-activity economic groups. Due to the existence of financial conglomerates, market concentration is considerably greater than conventional measures would suggest. Financial conglomerates are already leveraging many operational synergies, which are expected to increase following the process of consolidation that is already underway in some of them. At the same time, a single integrated financial supervisor has recently been created.

An analytical approach is developed to qualitatively assess the benefits of proposed reforms, given the difficulties of a priori quantifying their impact. The approach seeks to operationalize the paper's objective by applying general principles (market orientation, contestability, risk mitigation and transparency, efficiency) to screen suitable reforms, and an evaluation framework (benefits, risks, ease of implementation, impact) to assess their relative strengths and weaknesses. Selected reforms are also compared to international practice, particularly in selected peer countries (Chile, Mexico, Spain).

Five specific and four general reforms to the financial system structure are proposed, and are summarized in the Table below. Each of the former affects (at least) one 
particular type of financial intermediary, while the latter are cross-cutting since they affect - directly or indirectly - all entities that form part of the financial system.

\begin{tabular}{|c|c|l|l|}
\hline $\begin{array}{c}\text { Specific } \\
\text { Recommendations }\end{array}$ & $\begin{array}{c}1 \\
2\end{array}$ & $\begin{array}{l}\text { Allow banks to offer financial leasing services directly } \\
\text { Introduce a specialized vehicle whose exclusive responsibility would be the management of } \\
\text { collective investment schemes } \\
\text { Allow banks to offer services currently provided by fiduciarias, with the exception of collective } \\
\text { investment schemes }\end{array}$ \\
Allow banks to offer all types of investment banking services, with the exception of long-term equity \\
investments in the real sector \\
Develop a full-fledged investment banking vehicle by strengthening Comisionistas de Bolsa and \\
eliminating Corporaciones Financieras
\end{tabular}

The motivations underlying the specific recommendations can be conceptually classified into exclusivity (i.e. the current framework unnecessarily restricts a financial activity to a non-bank vehicle, or prohibits it altogether), fragmentation (i.e. the current framework leads to the improper fragmentation of a financial activity across different vehicles that operate in distinct market segments and are subject to different regulations) and obsolescence (i.e. the historical rationale for the existence of certain vehicles is no longer valid given recent market developments).

Certain specific reforms - such as, for example, allowing banks to directly offer financial leasing, fiduciary activities and most investment banking services - encourage greater market choice and potentially increase operational efficiencies. The reforms also promote competition since, in addition to extending bank permissible activities, they allow niche players to continue operating in each market via specialized vehicles. Other specific reforms - such as, for example, introducing a specialized vehicle to manage collective investment schemes and developing a full-fledged investment banking vehicle - reduce regulatory arbitrage and conflicts of interest, as well as potentially stimulate market development and encourage greater efficiency via scale economies. General reforms introduce greater legal certainty, transparency and understanding by market participants, ensure the consistent application of rules, and promote financial stability.

The aforementioned recommendations promote a more sound, transparent and market-oriented financial system, but their overall impact on the system's efficiency is likely to be moderate. The proposed reforms will also change relatively little in terms of supervisory or antitrust priorities, but would significantly strengthen the consolidated supervision of financial conglomerates. The authorities will need to develop a carefully sequenced reform roadmap that clearly distinguishes between shorter- and longer-term policy measures based on considerations such as relative importance, ease of implementation, potential for 'bundling', and the inter-dependence between reforms. 


\section{Introduction}

\section{The objective of this policy paper ${ }^{1}$ is to identify and propose legal and regulatory reforms to the financial system structure that would enhance efficiency and/or mitigate risks by:}

- Removing unnecessary regulatory barriers or filling in existing gaps in order to let market forces determine the most appropriate financial structure

- Clarifying, completing and ensuring consistency in the prudential framework.

Given the breadth of this topic, only selected high-level reform proposals are considered. The financial system structure can be addressed from many different dimensions, and the paper does not aim to cover all of them ${ }^{2}$. Its starting point is the current organizational set-up of the Colombian financial system and not an idealized model. Given tight time constraints and in light of fine-tuning and timing considerations that are beyond the scope of this exercise, an in-depth analysis of each reform proposal has not been attempted; this means that some proposals may require further research in order to provide sufficient details to policymakers for the elaboration of the required regulations. The document does not attempt to cover in detail the historical evolution of the financial structure and its characteristics, or specific modifications to existing laws and regulations. The current supervisory and antitrust framework is also not evaluated in detail, although potential implications stemming from the proposed reforms (and vice versa) will be identified and highlighted.

An analytical approach is developed to qualitatively assess the benefits of proposed reforms, given the difficulties of a priori quantifying their impact. The merits of each proposed reform (either legal or regulatory), which have been identified in the literature or through conversations with policy makers and the industry, are evaluated based on an analytical approach developed in this paper. The experience of structures in other countries is used to compare and contrast (where appropriate) the different approaches that have been taken in each area. However, although these reforms generate positive results in terms of the cost-benefit trade-off and impact, their quantification is hampered for several reasons. Firstly, many of the benefits - especially those related to the prudential framework - are indirect and are derived from a more transparent and sound financial system. Secondly, greater market choice implies that much will depend on the voluntary response of market participants, who may decide (for other reasons) not to take advantage of the additional flexibility in some of these measures. Finally, there are many details to be worked out among relevant parties for each reform proposal that would affect the end result, thus making it difficult to a priori estimate its (positive) impact.

\footnotetext{
${ }^{1}$ The document draws from recently-completed operational work undertaken as part of the World Bank's non-lending technical assistance program in Colombia.

${ }^{2}$ For example, the impact on financial system structure stemming from the tax code and from Central Bank foreign exchange regulations that influence onshore versus offshore bank operations is not considered.
} 


\section{The paper is structured as follows:}

- Brief review of the legal and regulatory framework and some stylized facts about the Colombian financial system (section II)

- Elaboration of an analytical approach to assess the relative attractiveness of different reforms, and description of five specific and four general reforms to the financial system structure that are supported by this approach (section III)

- Summary of the main conclusions and policy recommendations, including the likely implications for supervision and competition (section IV). 


\section{Background}

\section{A. Evolution of legal and regulatory framework}

The Colombian financial system had historically developed under a specialized model $^{3}$. This model had three main characteristics:

- specialized legal vehicles, each of them designed for different financial objectives, with specific and sometimes exclusive permissible activities;

- isolation between different financial system vehicles, through restrictions or prohibitions on cross-shareholdings and Board of Directors participation between financial companies;

- severe investment restrictions for deposit-taking institutions, including the prohibition of equity investments in the real sector.

Law 45/1990 introduced significant changes to this model. In particular, this law permitted equity participations between some financial companies, thereby converting the system into one of "multi-banking” (matrix-subsidiaries) and promoting the creation of financial conglomerates. The law also allowed some financial companies (but not banks) to invest in the real sector, permitted foreign investments in the financial sector, and accelerated the privatization process of nationalized financial companies.

Legal reforms during the last fifteen years have provided more flexibility but have not fundamentally changed the multi-banking model. As can be seen in the Table below, new laws introduced in the last 15 years have changed permissible activities for some entities (e.g. Law 795/2003), have created new financial institutions (Law 454/1998) and/or have eliminated existing ones (e.g. Law 546/1999). However, with the possible exception of the elimination of the housing bank vehicle (CAV, subsequently renamed $\mathrm{BECH}$ ), the model of specialized financial service provision has not been significantly affected. The consolidation of laws and regulations under the "Estatuto Orgánico del Sistema Financiero” (EOSF) in 1993 (and subsequently updated) defined financial institutions under the supervision of the Superintendencia de Bancos (Banking Superintendency) ${ }^{4}$ as being comprised of:

- credit institutions (banks, corporaciones financieras, compañías de financiamiento comercial and cooperativas financieras) responsible for financial intermediation

- financial service companies (fiduciarias, almacenes generales de depósito, sociedades administradoras de fondos de pensiones y de cesantía)

- $\quad$ sociedades de capitalización

- insurance companies, and insurance and reinsurance brokers.

\footnotetext{
${ }^{3}$ See, for example, Clavijo S. (2000).

${ }^{4}$ The EOSF did not cover stock exchanges or securities firms (e.g. comisionistas de bolsa), which were generally subject to separate laws (Ley de Valores) and whose regulation and supervision was primarily the responsibility of the Superintendencia de Valores (Securities Superintendency).
} 
Table 1: Main Legal Reforms to Financial System Structure (1990-2005)

\begin{tabular}{|l|l|}
\hline Law 45/1990 & Dismantles fiduciary sections of banks and obliges the creation of separate fiduciaria vehicle \\
Allows banks, CFCs and CFs to take majority equity positions in financial service companies (fiduciarias, leasing \\
companies, comisionistas de bolsa, almacenes generales de deposito and AFPs) \\
Denotes leasing companies as financial service companies \\
Establishes permissible activities for comisionistas de bolsa as a sociedad anonima, and places them under the \\
licensing and supervision of the Comisión Nacional de Valores \\
Establishes minimum capital required to operate a financial institution (different by type of entity)
\end{tabular}

The existing framework continues to require distinct institutional 'vehicles' in order to be able to offer a full range of financial services. The main vehicles are:

- establecimientos bancarios, which are commercial banks that can offer the full scale of retail (including mortgage) and corporate banking services with the exception of investment banking and financial leasing ${ }^{5}$

- Corporaciones Financieras (CFs), which can offer most corporate and investment banking services, but cannot fund themselves with demand deposits

- Compañías de Financiamiento Comercial (CFCs), which are finance companies offering lending and/or leasing services, but cannot fund themselves with demand deposits

- fiduciarias, which are a combination of asset management and trust/fiduciary activities vehicle

- comisionistas de bolsa, which are brokers and broker-dealers offering most investment banking and some fund management services

- insurance companies (life and non-life) and brokers

- sociedades administradoras de fondos de pensiones y de cesantía, which mainly manage mandatory defined contribution pension schemes (AFPs).

\footnotetext{
${ }^{5}$ There are also offshore bank subsidiaries of domestic banks, which mainly act as a conduit for foreign currency-related (deposit taking, loans, investments) and other activities that are not permitted onshore.
} 
Other financial institutions include cooperativas financieras (financial cooperatives), casas de cambio (foreign exchange houses), almacenes generales de depósito (bonded warehouses) and sociedades de capitalización (see section III for a description).

The current model is already de facto close to universal banking because of financial conglomerates, but it is more inefficient because their structures are not fully market-determined. Market consolidation, foreign entry and the partial relaxation of permissible activities over the last decade have mostly aligned Colombia's regulatory framework to international practice and have led to increasing conglomeration in the financial system ${ }^{6}$. However, the actual financial conglomerate structures are not fully market-determined as they are shaped by very specific prohibitions of equity participation across different financial intermediaries ${ }^{7}$. This has historically led to the duplication of resources, operational inefficiencies and lower economies of scale, while 'isolation’ has also inhibited cross-selling efforts across group companies.

\section{B. Market characteristics and recent developments}

Both the number of financial institutions and the relative importance of banks in the financial system have declined over the last 10 years. In particular, the number of financial (particularly credit) institutions has declined as many of them were merged, purchased by commercial banks or liquidated (see Table below) ${ }^{8}$. In fact, most of the burden of adjustment to the 1998-99 crisis fell on the smaller, independent and more specialized entities (i.e. CFs, CFCs, fiduciarias, financial cooperatives and housing banks) that followed distinct and heterogeneous business models ${ }^{9}$. In addition, the relative importance of institutional investors (i.e. AFPs, insurance companies and - partly - fiduciarias) has increased compared to the banking sector (see Figure below). This together with greater bond investments in bank portfolios - has contributed to the significant increase in daily market trading volumes over the same time period, particularly in fixed income (from Col\$1 trillion in 1995 to Col\$12 trillion in $2005^{10}$ ). However, the vast majority of institutional investor assets remains invested in government bonds - in fact, annual debt and equity issuance by the non-financial private sector between 2001-2005 is estimated to be around 1 percent of GDP - so banks continue to represent the main institutional vehicle for private sector financing.

\footnotetext{
${ }^{6}$ In fact, one could argue that the requirement to maintain specialized financial vehicles has supported the process of financial conglomeration.

${ }^{7}$ For example, while insurance companies can own banks, the latter cannot own other domestic banks and can only hold majority participations in fiduciarias, CFCs or CFs.

${ }^{8}$ As many as 35 entities were intervened for liquidation between 1998 and 2003, and another 20 were voluntarily liquidated by their shareholders.

${ }^{9}$ Facing the risk of a broader systemic crisis and a run on deposits in 1998-99, the Government embarked on a series of economic emergency measures to address financial system problems. These measures can be conceptually divided into those aiming primarily to restore the health of the system (financial system support operations) and those that provided support to debtors (relief or "alivios" and restructuring programs). Financial system support consisted of private and public sector bank cleanup and recapitalization operations.

${ }^{10}$ As of end-December 2005, US\$1 was equivalent to 2,288 Colombian pesos (Col\$).
} 
Table 2: Number of Financial Institutions (1995-2005)

\begin{tabular}{|c|c|c|c|c|c|}
\hline & 1995 & 2000 & & 2005 & \\
\hline Number of Institutions & 279 & 196 & & 154 & \\
\hline Commercial and Housing Banks & 41 & 30 & & 21 & \\
\hline Private domestic & 21 & & 15 & & 12 \\
\hline Public & 5 & & 4 & & 3 \\
\hline Foreign & 12 & & 11 & & 6 \\
\hline Solidarios & 3 & & 0 & & 0 \\
\hline Other Credit Institutions & 98 & 54 & & 32 & \\
\hline Corporaciones Financieras (CF) & 24 & & 8 & & 2 \\
\hline Compañias de Financiamiento Comercial (CFC) & 73 & & 32 & & 24 \\
\hline Financial Cooperatives & $N / A$ & & 13 & & 5 \\
\hline Organismos Cooperativos de Grado Superior (OCGS) & 1 & & 1 & & 1 \\
\hline Instituciones Oficiales Especiales (IOEs) & 6 & 9 & & 10 & \\
\hline Almacenes Generales de Deposito & 11 & 9 & & 6 & \\
\hline Insurance Companies & 60 & 50 & & 44 & \\
\hline Life & 35 & & 27 & & 24 \\
\hline Non-Life & 25 & & 23 & & 20 \\
\hline Sociedades de Capitalización & 8 & 5 & & 5 & \\
\hline Pension Funds & 9 & 6 & & 6 & \\
\hline Fiduciarias & 46 & 33 & & 30 & \\
\hline
\end{tabular}

Source: Superintendencia Financiera.

Note: IOEs refers to second-tier public development banks. Comisionistas de bolsa and other financial entities (e.g. sociedades administradoras de inversión) are excluded from the analysis because their respective numbers were not available for 1995.

Figure 1: Composition of Financial System Assets (1995-2005)

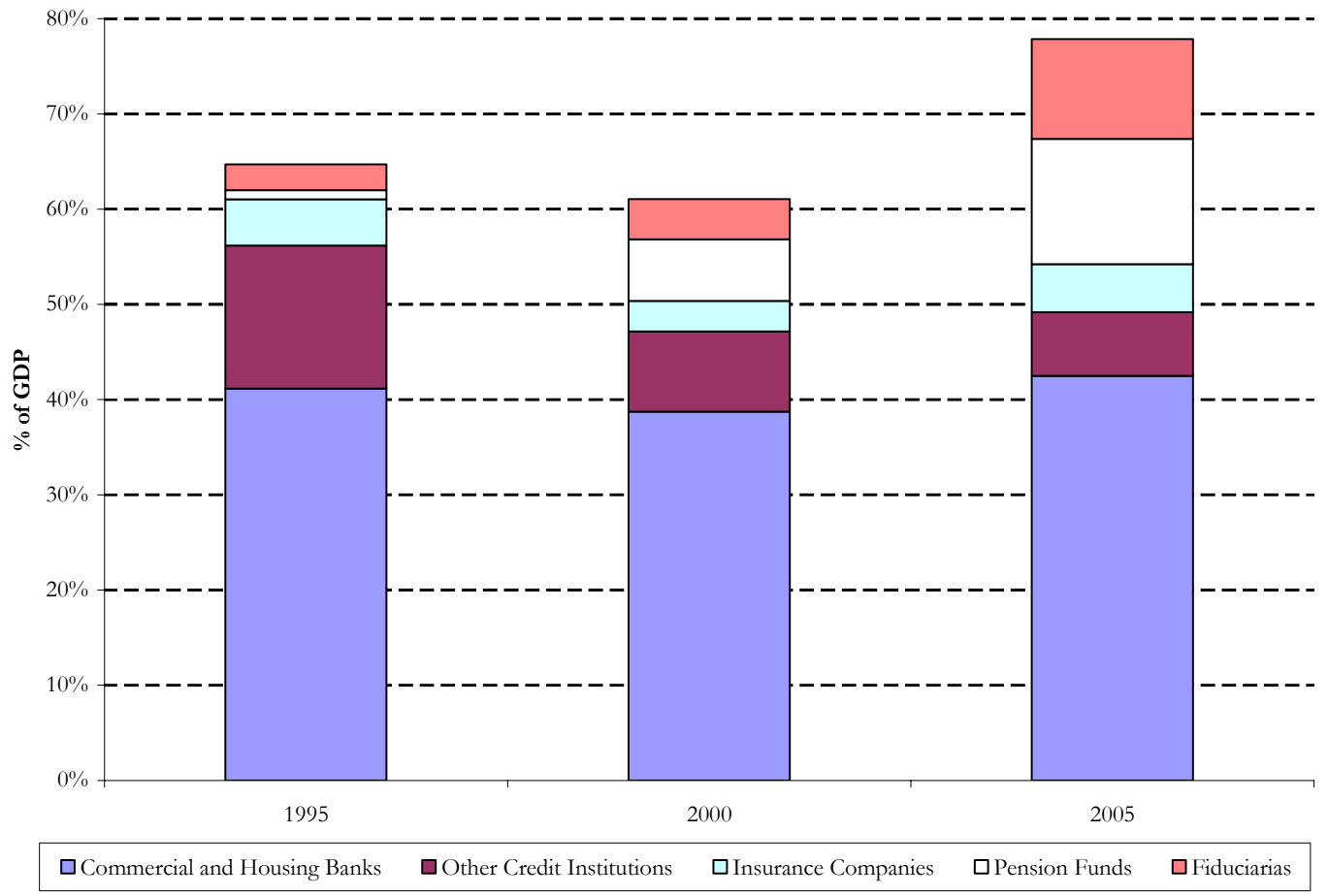

Source: Superintendencia Financiera and own analysis.

Note: The above figure shows total assets for credit institutions (including sociedades de capitalización), total assets under

management for insurance companies and pension funds, and only investment assets for fiduciarias. Other financial institutions are excluded from the analysis either because of small asset size and data unavailability (e.g. comisionistas de bolsa, administradoras de inversión) or because they are already indirectly captured in the above figures (e.g. IOEs). 
The banking sector has mostly recovered from the 1999 crisis, although financial intermediation has been slow to pick up. After a long period of shrinkage due to the crisis, banking sector size begun to recover in 2004 and standard financial performance indicators - solvency, profitability, efficiency and asset quality - have significantly improved (see Table below). The recovery can be attributed to a combination of factors, such as the resumption of economic growth, a slightly increasing net interest margin in spite of declining interest rates, the post-crisis recapitalization programs (particularly for public banks), as well as the exit and/or restructuring of a significant quantity of nonperforming assets. However, financial intermediation has not yet recovered - in particular, net loans and leases plummeted from 36 percent to 25 percent of GDP over 1998-2003 and have only started to increase again in the last two years. By contrast, security holdings (mostly sovereign) have more than doubled as a proportion of GDP over this period and now represent one-third of banking sector assets.

Table 3: Financial Performance of Credit Institutions (1998-2005)

\begin{tabular}{|c|c|c|c|c|c|c|c|c|}
\hline & Dec-98 & Dec-99 & Dec-00 & Dec-01 & Dec-02 & Dec-03 & Dec-04 & Dec-05 \\
\hline \multicolumn{9}{|l|}{ NOMINAL GROWTH RATES } \\
\hline Net Loans \& Leases & & $-5 \%$ & $-9 \%$ & $0 \%$ & $5 \%$ & $7 \%$ & $21 \%$ & $18 \%$ \\
\hline Securities & & $29 \%$ & $42 \%$ & $29 \%$ & $13 \%$ & $16 \%$ & $28 \%$ & $18 \%$ \\
\hline Deposits & & $8 \%$ & $2 \%$ & $9 \%$ & $5 \%$ & $8 \%$ & $21 \%$ & $17 \%$ \\
\hline Total Assets & & $1 \%$ & $0 \%$ & $5 \%$ & $6 \%$ & $9 \%$ & $18 \%$ & $17 \%$ \\
\hline \multicolumn{9}{|l|}{ AS $\%$ OF GDP } \\
\hline Net Loans \& Leases & $36 \%$ & $32 \%$ & $25 \%$ & $23 \%$ & $23 \%$ & $22 \%$ & $23 \%$ & $25 \%$ \\
\hline Securities & $7 \%$ & $8 \%$ & $10 \%$ & $12 \%$ & $12 \%$ & $13 \%$ & $15 \%$ & $16 \%$ \\
\hline Deposits & $33 \%$ & $33 \%$ & $29 \%$ & $29 \%$ & $28 \%$ & $27 \%$ & $30 \%$ & $32 \%$ \\
\hline Total Assets & $57 \%$ & $53 \%$ & $46 \%$ & $45 \%$ & $44 \%$ & $42 \%$ & $45 \%$ & $48 \%$ \\
\hline \multicolumn{9}{|l|}{ SOLVENCY } \\
\hline Net Worth/Total Assets & $10.6 \%$ & $11.0 \%$ & $11.3 \%$ & $11.2 \%$ & $11.0 \%$ & $11.6 \%$ & $12.1 \%$ & $12.3 \%$ \\
\hline Capital Adequacy Ratio & & $10.9 \%$ & $13.2 \%$ & $13.3 \%$ & $12.5 \%$ & $13.1 \%$ & $13.8 \%$ & $13.5 \%$ \\
\hline \multicolumn{9}{|l|}{ PROFITABILITY } \\
\hline Return on Average Assets (ROAA) & $-2.5 \%$ & $-3.5 \%$ & $-2.3 \%$ & $0.1 \%$ & $1.1 \%$ & $1.9 \%$ & $2.7 \%$ & $2.7 \%$ \\
\hline Return on Average Net Worth (ROAE) & $-21.0 \%$ & $-32.6 \%$ & $-20.7 \%$ & $1.1 \%$ & $9.6 \%$ & $17.1 \%$ & $23.0 \%$ & $22.1 \%$ \\
\hline Net Interest Margin (Net Interest Income/Average Assets) & $4.1 \%$ & $3.0 \%$ & $3.5 \%$ & $3.1 \%$ & $3.4 \%$ & $3.9 \%$ & $4.2 \%$ & $4.1 \%$ \\
\hline \multicolumn{9}{|l|}{ EFFICIENCY } \\
\hline Cost-Income Ratio (Operating Expenses/Gross Income) & $71 \%$ & $81 \%$ & $80 \%$ & $74 \%$ & $71 \%$ & $62 \%$ & $54 \%$ & $51 \%$ \\
\hline Operating Expenses/Average Assets & & $6.4 \%$ & $6.7 \%$ & $6.4 \%$ & $6.3 \%$ & $6.1 \%$ & $5.4 \%$ & $4.9 \%$ \\
\hline Labor Costs/Operating Expenses & $51 \%$ & $46 \%$ & $42 \%$ & $43 \%$ & $43 \%$ & $44 \%$ & $46 \%$ & $45 \%$ \\
\hline Number of Bank Employees & 76,478 & 69,766 & 59,908 & 56,758 & 55,658 & 54,474 & 55,678 & \\
\hline \multicolumn{9}{|l|}{ ASSET QUALITY } \\
\hline Past Due Loans/Total Gross Loans & $10.7 \%$ & $13.6 \%$ & $11.0 \%$ & $9.7 \%$ & $8.7 \%$ & $6.8 \%$ & $3.3 \%$ & $2.6 \%$ \\
\hline Non-Performing Loans/Total Gross Loans & & $16.3 \%$ & $16.4 \%$ & $15.4 \%$ & $13.6 \%$ & $10.5 \%$ & $5.8 \%$ & $4.4 \%$ \\
\hline Loan Loss Provisions/Total Gross Loans & $4.1 \%$ & $5.0 \%$ & $6.2 \%$ & $7.5 \%$ & $7.6 \%$ & $6.7 \%$ & $4.8 \%$ & $4.3 \%$ \\
\hline Loan Loss Provisions/Non-Performing Loans & & $31 \%$ & $38 \%$ & $49 \%$ & $56 \%$ & $64 \%$ & $82 \%$ & $97 \%$ \\
\hline \multicolumn{9}{|l|}{ Gross Loan Composition } \\
\hline Commercial & $53 \%$ & $55 \%$ & $59 \%$ & $58 \%$ & $62 \%$ & $63 \%$ & $67 \%$ & $65 \%$ \\
\hline Consumer & $18 \%$ & $13 \%$ & $14 \%$ & $16 \%$ & $16 \%$ & $18 \%$ & $20 \%$ & $24 \%$ \\
\hline Microcredit & & & & & $1 \%$ & $1 \%$ & $1 \%$ & $2 \%$ \\
\hline Mortgages & $29 \%$ & $31 \%$ & $27 \%$ & $26 \%$ & $22 \%$ & $18 \%$ & $11 \%$ & $9 \%$ \\
\hline \multicolumn{9}{|l|}{ MEMO ITEM } \\
\hline Real GDP Growth & $0.6 \%$ & $-4.2 \%$ & $2.9 \%$ & $1.5 \%$ & $1.9 \%$ & $4.1 \%$ & $4.1 \%$ & $5.1 \%$ \\
\hline Inflation Rate (end-period) & $16.7 \%$ & $9.2 \%$ & $8.7 \%$ & $7.6 \%$ & $7.0 \%$ & $6.5 \%$ & $5.5 \%$ & $5.0 \%$ \\
\hline Nominal 90-day deposit rate (\% p.a.) & $34.1 \%$ & $15.8 \%$ & $13.4 \%$ & $11.5 \%$ & $7.7 \%$ & $7.9 \%$ & $7.7 \%$ & \\
\hline Exchange Rate vs. USD (end-period) & 1,542 & 1,874 & 2,229 & 2,291 & 2,865 & 2,778 & 2,390 & 2,288 \\
\hline
\end{tabular}

Source: Superintendencia Financiera, IMF, Asobancaria and own analysis.

Note: Credit institutions include commercial and housing banks, CFs and CFCs, but exclude IOEs and financial cooperatives.

It is unclear to what extent Colombia's current financial system structure hinders performance, at least when compared with regional peers. Some academic studies in the past have convincingly argued that Colombia's financial system structure has contributed to high operational costs. As can be seen in the Table below, although Colombia has a proportionally smaller and 'shallower' - in terms of access - financial 
system than Chile and Brazil (but not Mexico), it is currently not very different in overall bank financial performance. In particular, relatively higher revenue-generating capacity helps to offset higher operating expenses (relative to assets), potentially indicating scope for operational improvements arising from greater consolidation and scale economies. However, the extent to which such improvements can be attained solely by changes to the current financial system structure (as opposed to the macroeconomic environment or individual financial group strategies) remains unclear.

Table 4: Comparative Performance of Financial Systems in Selected Countries (latest available)

\begin{tabular}{|c|c|c|c|c|c|}
\hline & Colombia & Chile & Brazil & Mexico & Year \\
\hline \multicolumn{6}{|l|}{ SIZE / DEPTH } \\
\hline Total Bank Assets (US\$ Billion) & 59 & 119 & 715 & 209 & 2005 \\
\hline Total Bank Assets (\% of GDP) & $42 \%$ & $95 \%$ & $86 \%$ & $27 \%$ & 2005 \\
\hline Stock Market Capitalization (\% of GDP) & $26 \%$ & $124 \%$ & $55 \%$ & $25 \%$ & 2004 \\
\hline Number of Listed Firms & 114 & 239 & 357 & 152 & 2004 \\
\hline Amount Outstanding of Domestic Private Bonds (\% of GDP) & $8 \%$ & $23.3 \%$ & $12.6 \%$ & $3.4 \%$ & 2004 \\
\hline \multicolumn{6}{|l|}{ ACCESS } \\
\hline Credit to the Private Sector (\% of GDP) & $23 \%$ & $62 \%$ & $36 \%$ & $17 \%$ & 2004 \\
\hline Branches per 100,000 People & 8.7 & 9.4 & 14.6 & 7.6 & $2002-03$ \\
\hline ATMs per 100,000 People & 9.6 & 24.0 & 17.8 & 16.6 & 2002-04 \\
\hline \multicolumn{6}{|l|}{ SOLVENCY } \\
\hline Bank Capital to Assets & $11.4 \%$ & $6.8 \%$ & $16.0 \%$ & $12.0 \%$ & Sep-Dec. 2005 \\
\hline Bank Capital Adequacy Ratio & $12.5 \%$ & $14.2 \%$ & $18.2 \%$ & $14.4 \%$ & Sep. 2005 \\
\hline \multicolumn{6}{|l|}{ PROFITABILITY } \\
\hline Bank Return on Assets & $2.5 \%$ & $1.4 \%$ & $2.0 \%$ & $1.9 \%$ & Sep-Dec. 2005 \\
\hline Bank Return on Equity & $25.7 \%$ & $18.7 \%$ & $20.8 \%$ & $15.8 \%$ & 2005 \\
\hline \multicolumn{6}{|l|}{ EFFICIENCY } \\
\hline Bank Cost-Income Ratio (Operating Expenses/Gross Income) & $51 \%$ & $52 \%$ & $58 \%$ & $60 \%$ & 2005 \\
\hline Bank Operating Expenses/Total Assets & $4.6 \%$ & $2.3 \%$ & $6.9 \%$ & $4.6 \%$ & 2005 \\
\hline \multicolumn{6}{|l|}{ ASSET QUALITY } \\
\hline Bank Non-Performing Loans/Total Loans & $3.2 \%$ & $1.0 \%$ & $4.1 \%$ & $2.0 \%$ & Jun-Dec. 2005 \\
\hline Bank Provisions/Non-Performing Loans & $144 \%$ & $166 \%$ & $153 \%$ & $232 \%$ & Mar-Sep. 2005 \\
\hline \multicolumn{6}{|l|}{ FINANCIAL INFRASTRUCTURE } \\
\hline Legal Rights Index & 4 & 4 & 2 & 2 & 2005 \\
\hline Credit Information Index & 4 & 6 & 5 & 6 & 2005 \\
\hline Investor Protection Index & 5.7 & 5.7 & 5.3 & 3.7 & 2005 \\
\hline Cost of Enforcing Contracts (\% of Debt) & $18.6 \%$ & $10.4 \%$ & $15.5 \%$ & $20.0 \%$ & 2005 \\
\hline
\end{tabular}

Source: Superintendencies and Central Banks, IMF, World Bank, Standard and Poor's, BIS and own analysis.

Note: Some financial performance ratios are based on reported Financial Soundness Indicators (FSIs) that are not fully comparable across countries. The ratios for Colombia include all credit institutions and might differ from those estimated using figures provided by the Superintendencia Financiera (previous Table). The size of the private sector debt market in Colombia is an estimate.

Colombia's financial system is dominated by financial conglomerates, the most important of which belong to domestic mixed-activity economic groups. Using a variant of the Joint Forum definition to account for the presence and importance of AFPs in Colombia's financial system ${ }^{11}$, it can be seen in the Figure and Tables below that

\footnotetext{
${ }^{11}$ The Joint Forum was established in 1996 under the aegis of the Basel Committee on Banking Supervision, the International Organization of Securities Commissions (IOSCO) and the International
} 
financial conglomerates - i.e. a group of companies under common control whose exclusive or predominant activities consist of providing significant services in at least two different financial sectors (banking, securities, insurance, pensions) - dominate the financial system ${ }^{12}$. The most important financial conglomerates are controlled by domestic mixed-activity economic groups. The two main groups (Aval and Sindicato) each own several financial institutions and together represented half of total bank assets as of December 2005, up from 31 percent as of the end of 1998.

Table 5: Five Largest Firms by Market Segment (2005)

\begin{tabular}{|c|c|c|c|c|c|c|}
\hline Ranking by Size & Banks & CFCs & Fiduciarias & Comisionistas & Insurance & Pensions \\
\hline 1 & $\begin{array}{c}\text { Bancolombia } \\
\text { (Grupo Sindicato) }\end{array}$ & $\begin{array}{c}\text { Suleasing } \\
\text { (Grupo Sindicato) }\end{array}$ & $\begin{array}{c}\text { Fiducolombia } \\
\text { (Grupo Sindicato) }\end{array}$ & $\begin{array}{c}\text { Interbolsa } \\
\text { (independent) }\end{array}$ & $\begin{array}{l}\text { Suramericana Vida } \\
\text { (Grupo Sindicato) }\end{array}$ & $\begin{array}{c}\text { Porvenir } \\
\text { (Grupo Aval) }\end{array}$ \\
\hline 2 & $\begin{array}{c}\text { Banco de Bogota } \\
\text { (Grupo Aval) }\end{array}$ & $\begin{array}{l}\text { Leasing Colombia } \\
\text { (Grupo Sindicato) }\end{array}$ & $\begin{array}{c}\text { Previsora } \\
\text { (State-owned) }\end{array}$ & $\begin{array}{c}\text { Inversionistas de } \\
\text { Colombia (independent) }\end{array}$ & $\begin{array}{c}\text { Vidalfa } \\
\text { (Grupo Aval) }\end{array}$ & $\begin{array}{l}\text { Proteccion } \\
\text { (Grupo Sindicato) }\end{array}$ \\
\hline 3 & BBVA & $\begin{array}{l}\text { Leasing de Occidente } \\
\text { (Grupo Aval) }\end{array}$ & $\begin{array}{l}\text { Fiduciaria Bogota } \\
\text { (Grupo Aval) }\end{array}$ & $\begin{array}{c}\text { Correval } \\
\text { (independent) }\end{array}$ & $\begin{array}{l}\text { Suramericana Generales } \\
\text { (Grupo Sindicato) }\end{array}$ & $\begin{array}{l}\text { Horizonte } \\
\text { (BBVA) }\end{array}$ \\
\hline 4 & $\begin{array}{l}\text { Banco de Occidente } \\
\text { (Grupo Aval) }\end{array}$ & $\begin{array}{l}\text { Leasing de Credito } \\
\text { (Helm Financial) }\end{array}$ & $\begin{array}{l}\text { Fiduoccidente } \\
\text { (Grupo Aval) }\end{array}$ & $\begin{array}{c}\text { Suvalor } \\
\text { (Grupo Sindicato) }\end{array}$ & $\begin{array}{c}\text { Bolivar Vida } \\
\text { (Grupo Bolivar) }\end{array}$ & $\begin{array}{l}\text { Colfondos } \\
\text { (Citigroup) }\end{array}$ \\
\hline 5 & $\begin{array}{l}\text { Banco Agrario } \\
\text { (State-owned) }\end{array}$ & $\begin{array}{l}\text { Sufinancimiento } \\
\text { (Grupo Sindicato) }\end{array}$ & $\begin{array}{l}\text { Fidupopular } \\
\text { (Grupo Aval) }\end{array}$ & $\begin{array}{c}\text { Alianza } \\
\text { (independent) }\end{array}$ & $\begin{array}{c}\text { Previsora } \\
\text { (State-owned) }\end{array}$ & Santander \\
\hline $\begin{array}{l}\text { Market Share of } \\
\text { Top } 5\end{array}$ & $52 \%$ & $58 \%$ & $56 \%$ & $52 \%$ & $40 \%$ & $93 \%$ \\
\hline
\end{tabular}

Source: Superintendencia Financiera and own analysis.

Note: Size is based on total assets (banks and CFCs), annual debt and equity buying volumes (comisionistas de bolsa), total assets under management (fiduciarias), total life and non-life assets (insurance), and total AFP assets under management (pensions).

Table 6: Entities Controlled by Largest Financial Conglomerates (latest available)

\begin{tabular}{|c|c|c|c|c|c|}
\hline Market Segment & Grupo Aval & Grupo Sindicato & Grupo Bolivar & $\begin{array}{c}\text { Government of } \\
\text { Colombia }\end{array}$ & BBVA \\
\hline Banks & $\begin{array}{l}\text { Bogota, Occidente, Union } \\
\text { Colombiano, Popular, } \\
\text { Megabanco, Av. Vilas }\end{array}$ & Bancolombia & Davivienda & Agrario, Granbanco & BBVA \\
\hline CFs & Corfivalle & Colcorp & & & \\
\hline CFCs & $\begin{array}{c}\text { Leasing del Valle, Leasing } \\
\text { Bogota, Leasing de Occidente, } \\
\text { Leasing Popular }\end{array}$ & $\begin{array}{l}\text { Comercia, } \\
\text { Sufinanciamiento, } \\
\text { Leasing Colombia, } \\
\text { Suleasing }\end{array}$ & Leasing Bolivar & Leasing Bancoldex & \\
\hline Fiduciarias & $\begin{array}{l}\text { Fidupopular, Fiduvalle, } \\
\text { Fiduoccidente, Bogota, } \\
\text { Fiducomercio, Fidunion }\end{array}$ & Fiducolombia & $\begin{array}{l}\text { Fiduciaria Davivienda, } \\
\text { Fidusuperior }\end{array}$ & $\begin{array}{l}\text { Fiduciaria Previsora, } \\
\text { Ffiducafe, Fiducentral, } \\
\text { Fiduagraria, Fiducoldex }\end{array}$ & Fiduciaria BBVA \\
\hline Comisionistas & $\begin{array}{c}\text { Casa de Bolsa, Valores Bogota, } \\
\text { Valores de Occidente, Valores } \\
\text { del Popular }\end{array}$ & Suvalor & Davivalores & & BBVA Valores \\
\hline $\begin{array}{l}\text { Sociedades de } \\
\text { Capitalización }\end{array}$ & & $\begin{array}{l}\text { Capitalizadora } \\
\text { Suramericana }\end{array}$ & Bolivar & & \\
\hline Insurance & Vidalfa, Alfa Generales & $\begin{array}{c}\text { Suramericana Vida, } \\
\text { Suratep, Suramericana } \\
\text { Generales }\end{array}$ & $\begin{array}{c}\text { Bolivar Vida, Bolivar } \\
\text { Generales }\end{array}$ & $\begin{array}{c}\text { Previsora Vida, } \\
\text { Previsora Generales }\end{array}$ & $\begin{array}{c}\text { BBVA Vida, BBVA } \\
\text { Seguros }\end{array}$ \\
\hline Pensions & AFP Porvenir & AFP Protección & & & AFP Horizonte \\
\hline
\end{tabular}

Source: Superintendencia Financiera, own analysis.

Note: All firms controlled by a financial conglomerate (the Government of Colombia is included here) are shown per market segment.

Association of Insurance Supervisors (IAIS), in order to take forward the work of the Tripartite Group on a range of issues relating to the supervision of financial conglomerates.

12 The dominance of financial conglomerates in the securities markets is much greater than the figures shown by comisionistas de bolsa, since the total 2005 debt buying volumes by banks (most of which are owned by financial conglomerates) was double the volume of comisionistas. 
Figure 2: Conglomeration by Type of Financial Entity (latest available)

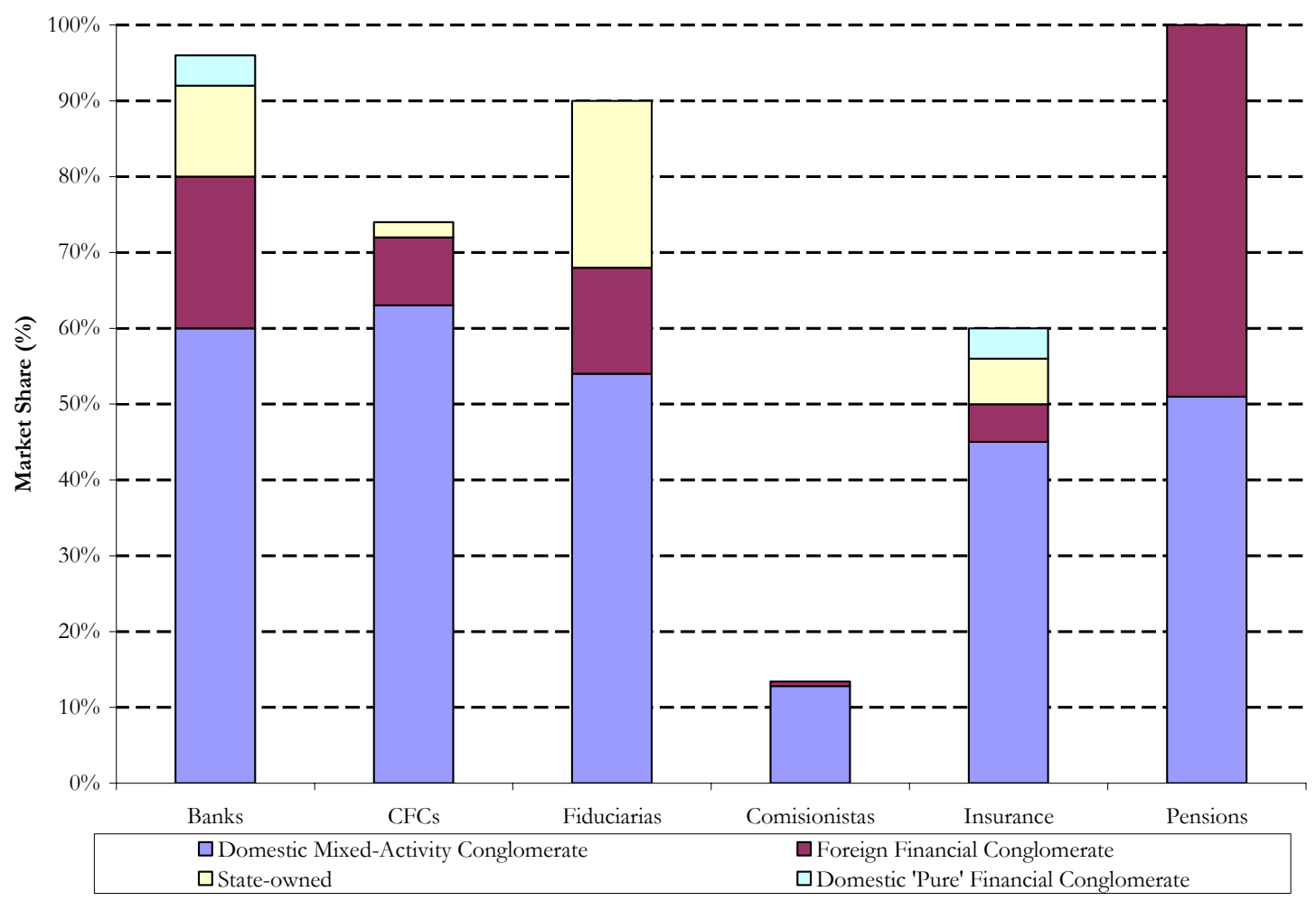

Source: Superintendencia Financiera and own analysis.

Note: Percentages are market shares of all firms controlled by a group for each type of financial vehicle (the Government of

Colombia is classified separately here). They are based on total assets (banks and CFCs), total debt and equity buying volumes for 2005 (comisionistas de bolsa), total assets under management (fiduciarias), total life and non-life assets (insurance), and total AFP assets under management (pensions).

Table 7: Classification of Financial Conglomerates (latest available)

\begin{tabular}{|c|c|c|c|c|c|c|c|c|}
\hline \multirow{2}{*}{ Financial Conglomerate } & \multicolumn{6}{|c|}{ Market Share } & \multirow{2}{*}{$\begin{array}{c}\text { Non-Financial } \\
\text { Activities }\end{array}$} & \multirow{2}{*}{ Banking Sector Presence } \\
\hline & Banks & CFCs & Fiduciarias & Comisionistas & Insurance & Pensions & & \\
\hline Grupo Aval & $29 \%$ & $19 \%$ & $25 \%$ & $4 \%$ & $9 \%$ & $27 \%$ & $\begin{array}{l}\text { Construction and } \\
\text { real estate }\end{array}$ & $\begin{array}{c}4 \text { banks (Bogota, Occidente, } \\
\text { Villas, Popular) }\end{array}$ \\
\hline Grupo Sindicato & $20 \%$ & $41 \%$ & $25 \%$ & $8 \%$ & $22 \%$ & $24 \%$ & Cement, retail, food & $\begin{array}{l}\text { Recently consolidated activities } \\
\text { into one bank (Bancolombia) }\end{array}$ \\
\hline Grupo Bolivar & $7 \%$ & $3 \%$ & $3 \%$ & $1 \%$ & $9 \%$ & & Construction & Davivienda \\
\hline State-owned & $12 \%$ & $2 \%$ & $22 \%$ & & $6 \%$ & & & Banco Agrario, Granbanco \\
\hline BBVA & $11 \%$ & & $3 \%$ & $0 \%$ & $3 \%$ & $17 \%$ & & $\begin{array}{l}\text { BBVA acquired Granahorrar in } \\
\text { privatization tender in late } 2005\end{array}$ \\
\hline Citigroup & $3 \%$ & $1 \%$ & $6 \%$ & & & $14 \%$ & & Citibank \\
\hline Santander & $3 \%$ & & $2 \%$ & $0 \%$ & & $11 \%$ & & Santander \\
\hline Skandia & & & $1 \%$ & & $2 \%$ & $7 \%$ & & N/A \\
\hline Mercantil Colpatria & $3 \%$ & & $1 \%$ & & $7 \%$ & & Construction & Red Multibanca Colpatria \\
\hline Helm Financial Services & $2 \%$ & $8 \%$ & $2 \%$ & $0 \%$ & & & & Banco de Credito \\
\hline Fundacion Social & $4 \%$ & & $0 \%$ & & $2 \%$ & & & Banco Caja Social \\
\hline
\end{tabular}

Source: Superintendencia Financiera and own analysis.

Note: Percentages are market shares of all firms controlled by a group (the Government of Colombia is also included here) for each type of financial vehicle. They are based on total assets (banks and CFCs), total debt and equity buying volumes for 2005

(comisionistas), total assets under management (fiduciarias), total life and non-life assets (insurance), and total AFP assets under management (pensions). Foreign and domestic entities that are primarily active in only one financial sector (e.g. Banistmo and Banco GNB Sudameris in banking, AIG and RSA in insurance) are excluded from the definition of financial conglomerates. 
Due to the existence of financial conglomerates, market concentration is considerably greater than conventional measures would suggest. For example, bank concentration - as measured by the Herfindahl Index (HI) of asset share at the individual bank level - was only 877 as of end-2005, which is significantly below the level of a concentrated market ${ }^{13}$. However, this calculation ignores the presence of financial conglomerates such as, for example, Grupo Aval, which controls four banks, each with its own CFC, fiduciaria and comisionista de bolsa. Taking these into account and treating the two public-owned banks as one group, the adjusted HI based on December 2005 figures rises to 1655, indicating a considerably greater market concentration.

Financial conglomerates are already leveraging many operational synergies. There exist different levels of collaboration and operational integration across different financial groups. Management control is typically exercised at the level of each financial entity, subject to an overall group direction dictated by the main controller(s), including via participation in the relevant Board of Directors. Sales distribution contracts ("contratos de red"), which are permissible under the current regulations, allow insurance companies, sociedades de capitalización, fiduciarias and comisionistas to sell their services using the network of the group's credit institutions; in addition, CFCs and CFs can use the group bank's branches to sell certificates of deposit. Some financial groups also share procurement, office space, back office processing, systems and risk management, although the practice differs depending on group strategy and the interpretation of the relevant laws and regulations (see General Reform 2). As a result, many of the efficiency benefits stemming from common ownership have been attained, albeit in a haphazard and inconsistent manner.

A process of restructuring and consolidation is already underway in some financial conglomerates to allow them to compete more effectively and access new capital. For example, Grupo Sindicato recently completed the merger of its three main credit institutions (Bancolombia, CFC Corfinsura and Conavi). In addition, Grupo Aval has merged its two CFs (Corfivalle and Corficolombiana), while the two banks respectively controlled by Fundación Social (Banco Caja Social and Banco Colmena) and by Grupo Bolivar (Davivienda and Bansuperior) have also merged. Some of this activity has allegedly been prompted by the forthcoming free trade agreement with the United States, which is expected to attract foreign investors in the financial system. It has also been facilitated by the improvement in the macroeconomic environment and bank financial performance over the last few years, as evidenced by the successful privatizations of Granahorrar (purchased by BBVA) and Megabanco (purchased by Grupo Aval ${ }^{14}$ ) in the last nine months. The ongoing, market-driven process of creating larger financial institutions could lead to even greater efficiency gains because of economies of scale arising from operational integration.

\footnotetext{
${ }^{13}$ The $\mathrm{HI}$ is a measure of market concentration, which is calculated as the sum of the squares of relative shares and lies between 0 and 10,000. According to the merger guidelines of the U.S. Department of Justice, a post-merger HI of 1,800 and over indicates a concentrated market, an HI between 1,000 and 1,800 , moderately concentrated, and an $\mathrm{HI}$ below 1,000, not concentrated.

${ }^{14}$ Grupo Aval has also acquired another small bank (Banco Union Colombiano) in December 2005, which it will subsume under Banco de Occidente.
} 
A single integrated financial supervisor has recently been created. In particular, the banking, insurance and pensions supervisory agency (Superintendencia Bancaria, $\mathrm{SB}$ ) and the securities supervisory agency (Superintendencia de Valores, SV) merged in January 2006 into an integrated financial supervisor (Superintendencia Financiera, SF). Consolidation of supervisory responsibilities is supported as a means of reducing interagency coordination and operating costs, mitigating regulatory arbitrage and strengthening overall financial regulation and supervision, although the technical and organizational challenges of smoothly integrating the two agencies remain significant. 


\section{Analytical Approach and Proposed Reforms}

\section{A. Analytical Approach}

In order to assess the attractiveness of different reform options, an analytical approach has been developed and is described in this section. As mentioned earlier, the main objective of this exercise is to identify and propose legal and regulatory reforms to the financial system structure that would enhance efficiency and/or mitigate risks. The analytical approach seeks to operationalize this objective by developing general principles to guide all proposed reforms and an evaluation framework to assess the specific merits and weaknesses of individual reforms. As can be deduced, the approach is not 'anchored' on a specific industrial organization model but rather on a practical costbenefit analysis of each proposed reform based on the aforementioned approach, with the starting point being the current organizational set-up of the Colombian financial system.

General principles are based on good international practice in financial sector reform and facilitate the identification of suitable reforms. The four interrelated principles mentioned below - derived from international experience in financial sector reform - provide a set of criteria/desired features with which to compare the relative attractiveness of different reforms:

- Market orientation - reforms should follow actual market developments and allow market choice (for example, by permitting banks to choose whether to offer a specific product directly or via a separate vehicle) to the extent that they do not unduly increase risks

- Contestability - given the dominant presence of a few large financial groups, reforms should ensure that smaller or niche market players can compete effectively (for example, via specialized legal vehicles that do not require a full bank license, or via a single bank with more permissible activities)

- Risk mitigation and transparency - reforms should reduce (or at least not exacerbate) and make more transparent the existing risks in the financial system for both supervisors and end-users; these risks are defined broadly so as to cover systemic stability considerations (including access to the bank safety net), regulatory arbitrage and conflicts of interest.

- Efficiency - reforms should provide incentives for greater efficiency in the provision of financial services to end users, which can arise from greater economies of scale, better-structured internal operations (X-efficiency), and from a more consistent and clear legal framework.

The evaluation framework assesses the specific merits and weaknesses of individual reforms. In addition to the aforementioned general principles that 'screen' the selection of suitable reform options, there exist other considerations that policy makers need to take into account, such as the ease of implementation of these reforms and their potential impact on the financial system. Even though both of these factors are difficult to quantify a priori and depend on 'fine tuning' considerations requiring the active 
involvement of all relevant parties, they are relevant when evaluating the overall costbenefit trade-off. Timing and scope constraints prevent an in-depth analysis of each of these factors in this document, although some preliminary high-level observations are attempted in the next section. In sum, the evaluation framework for each specific reform proposal in this document comprises of the following components:

- Benefits - in terms of the proposed reform's impact on efficiency, transparency, competition, effective supervision etc.

- Risks - in terms of the proposed reform's failure to adequately address the issues and the potential exacerbation of systemic vulnerabilities (extension of the safety net), conflicts of interest, regulatory arbitrage etc.

- Ease of implementation for regulator/supervisor - in terms of adapting regulation and supervision to the proposed reform

- Ease of implementation for industry - in terms of the ability to adapt business structure and operations to the proposed reform ${ }^{15}$

- Impact - in terms of the proposed reform's overall impact (market practices, pricing etc.) on the financial system given the size, structure and conduct of the sector under consideration.

Proposed reforms are also considered in light of international practice and especially the experience of selected peer countries. In particular, specific reforms on different legal vehicles and permissible activities are compared and contrasted, where applicable, to the financial system structures of Chile, Mexico and Spain (the latter also being representative of European Union practice). These three countries were selected as appropriate comparators because they share similar legal systems and some of the same financial system characteristics as Colombia (e.g. presence of financial conglomerates), but are relatively more advanced in terms of size and sophistication.

Five specific and four general reforms to Colombia's financial system structure are proposed in the following section. Each of the former affects (at least) one particular type of financial intermediary, while the latter are cross-cutting in the sense that they affect - directly or indirectly - all entities that form part of the financial system. The likely merits and weaknesses of each reform, based on the aforementioned analytical approach, are described below.

\section{B. Specific Reform 1: Financial Leasing}

Recommendation: Allow banks to offer financial leasing services directly. Law 45/1990 qualified leasing companies as financial institutions while maintaining their exclusivity in the provision of financial leasing services and authorized banks, CFs and CFCs to own them. Law 35/1993 obliged the conversion of leasing companies into credit institutions (CFCs) and distinguished between two types of CFCs (ordinary/traditional CFCs and CFCs specialized in leasing) depending on the composition of their business;

\footnotetext{
${ }^{15}$ This component does not capture the more subjective issue of the industry's and/or individual market participants' willingness (as opposed to ability) to adapt to potential reforms.
} 
the latter measure was eliminated by Law 510/1999. The recommendation here would allow banks - in addition to CFCs - to directly offer such services if they so wish ${ }^{16}$.

Offering financial leasing directly via banks has become standard international practice. For example, Chile has permitted this practice since the late 1990s; as a result, many of the leasing companies have been absorbed by their respective group banks and the majority of leasing operations are currently provided by the banks themselves. Mexico allows the provision of financial leasing both directly by banks and via a separate non-bank legal vehicle ("Organizaciones y Actividades Auxiliares de Crédito") that can be owned by a bank, while commercial banks can also offer this product in Spain and other EU countries directly or through specialized vehicles.

This recommendation would allow market choice and potentially greater efficiencies, although it is not expected to have a large impact on the financial system. Such a reform would permit banks to choose whether to offer financial leasing directly, while it would allow niche players to continue operating in this market via CFCs. Assuming that some leasing-only CFCs currently owned by financial groups are subsumed into the group bank, the main benefits of this reform would be greater efficiencies ${ }^{17}$, potentially greater competition (as other banks enter this market) and direct access to lower-cost funding that could reduce product prices. The ease of implementation is relatively high for both regulators and the industry. However, the potential impact of this reform on the financial system - including the risk from extending the bank safety net to cover such activities ${ }^{18}$ - is likely to be minimal. Although this market has been growing fast in recent years (around 40 percent in 2005), it remains fairly small; gross leasing assets were Col\$5,240 billion as of end-2005 (around 8 percent of total loans and leases of credit institutions, or 2 percent of GDP) $)^{19}$. There are around 20 CFCs that are active in leasing, but the market is highly concentrated and already dominated by large financial groups (see Table below) - for example, Grupo Sindicato and Grupo Aval together control 7 CFCs active in leasing and more than twothirds of this market. In fact, all 9 CFCs that are predominantly focused on leasing are owned by financial conglomerates with banks.

\footnotetext{
${ }^{16}$ Law 795/2003 gave banks the right to directly offer housing leases, but that market remains very small.

17 These would include operational expense savings related to the elimination of separate external auditors, Board of Directors, supervisory reporting, administration (e.g. human resources, legal, compliance) and IT.

${ }^{18}$ CFCs are already subject to many of the same prudential standards as for banks (Law 795/2003 eliminated any remaining discrepancies), so there should be relatively little impact in moving leasing activities from one legal vehicle to another.

${ }^{19}$ See Arbelaez M.A., Villegas F. and Salazar N. (October 2004).
} 
Table 8: Size and Ownership of Five Largest Leasing CFCs (December 2005)

\begin{tabular}{lccc}
\hline & $\begin{array}{c}\text { Gross Leasing Assets } \\
\text { (Col\$ billion) }\end{array}$ & Market Share & Ownership \\
\hline Leasing Colombia & 2,321 & $44 \%$ & Grupo Sindicato \\
Leasing de Occidente & 890 & $17 \%$ & Grupo Aval \\
Leasing de Credito & 643 & $12 \%$ & Helm Financial Services \\
Leasing del Valle & 400 & $8 \%$ & Grupo Aval \\
Leasing Bolivar & 282 & $5 \%$ & Grupo Bolivar \\
\hline
\end{tabular}

Source: Superintendencia Financiera and own analysis.

\section{Specific Reform 2: Collective Investment Schemes}

Recommendation: Introduce a specialized vehicle whose exclusive responsibility would be the management of collective investment schemes. These schemes in Colombia have historically developed in a fragmented piece-meal manner ${ }^{20}$. This led to the co-existence of several types of funds subject to different - banking or securities regulations ${ }^{21}$ in spite of the common underlying characteristics of this activity ${ }^{22}$ (see Table and Figure below). The proposed reform would introduce a specialized entity operating under international regulatory standards whose mandate would be to consolidate and manage such collective investment schemes (i.e. FCO, FCE, FV and $\mathrm{FI})^{23}$. In addition, this entity could manage FPVs together with AFPs and insurance companies $^{24}$, as well as those FMIs whose management is sub-contracted to third parties. Fiduciarias and comisionistas de bolsa would no longer be allowed to directly manage collective investment schemes, but they (as well as banks) could own this specialized entity and could agree to distribute its products and/or those of third party providers.

Table 9: Types of Collective Investment Schemes by Provider

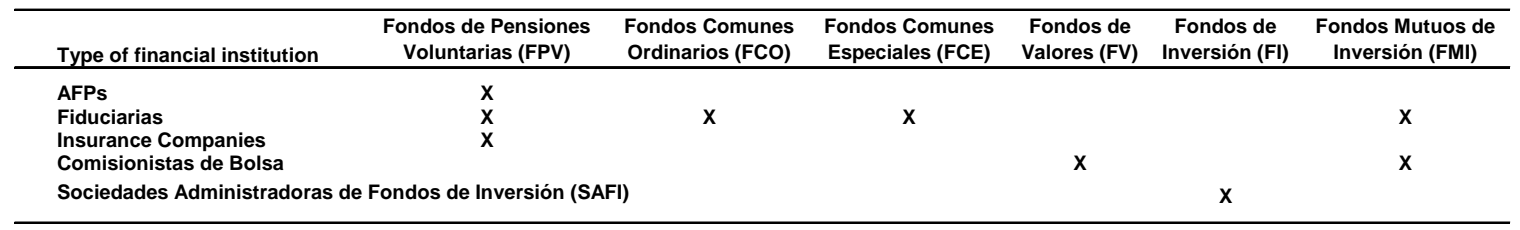

Source: Superintendencia Financiera

\footnotetext{
${ }^{20}$ Closed employer/employee-sponsored plans called Fondos Mutuos de Inversión (FMI) were created in 1959; Sociedades Administradoras de Fondos de Inversión (SAFI) managing Fondos de Inversión (FI) were created in 1980; comisionistas de bolsa managing Fondos de Valores (FV) were established in 1990; Fondos Comunes Ordinarios (FCO), Fondos Comunes Especiales (FCE) and voluntary pension funds (Fondos de Pensiones Voluntarias or FPV) managed by fiduciarias were introduced prior to the 1990's.

${ }^{21}$ These include, for example, differences in licensing procedures, minimum capital requirements, investment limits, internal controls, conduct rules, firewalls in relation to other provider activities etc.

${ }^{22}$ Investment pools related to the social security system and managed by AFPs (i.e. Fondos de Pensiones Obligatorios and Fondos de Cesantía) are excluded from the definition of collective investment schemes.

${ }^{23}$ Alternatively, this specialized entity could be based on an amended version of the SAFI, which is a type of exclusive fund management firm.

${ }^{24}$ Given its current structure (capped salary contributions with a tax exemption if held for at least 5 years), an FPV can also be considered as a type of collective investment scheme with tax benefits.
} 
Figure 3: Collective Investment Scheme Providers (December 2005)

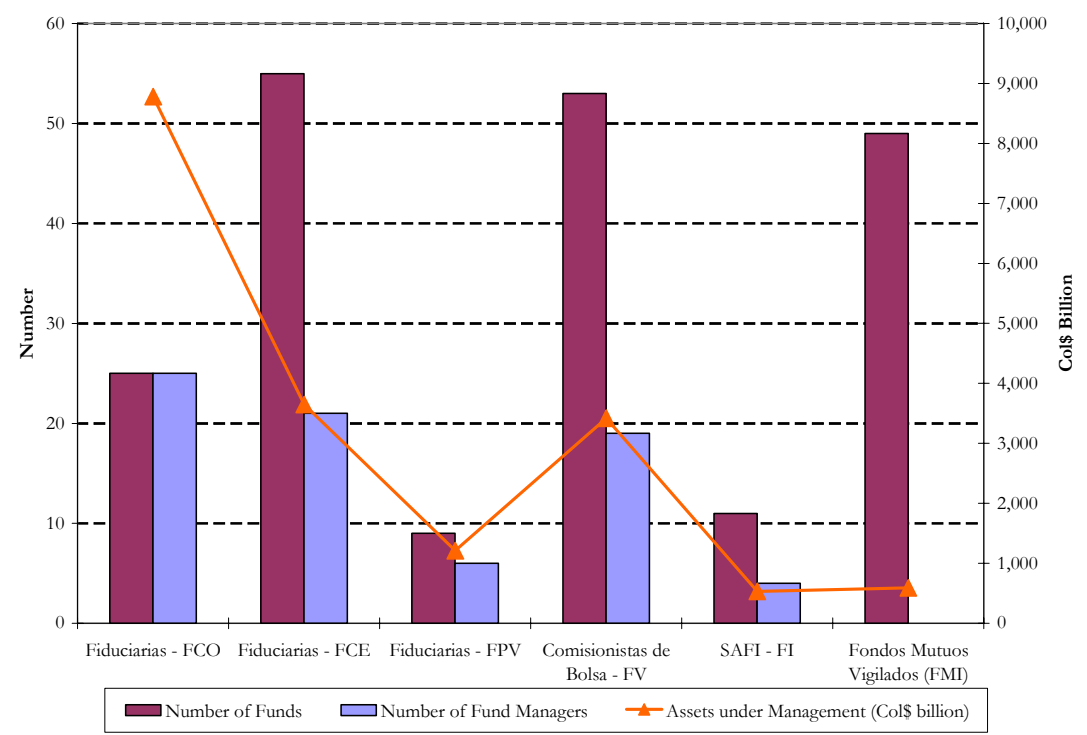

Source: Superintendencia Financiera, own analysis.

Note: FPVs managed by AFPs and insurance companies are not included. Many of the same fiduciarias offer FCOs, FCEs and FPVs, while the vast majority of fondos mutuos vigilados manage their own investments.

The existence of specialized exclusive vehicles for the management of collective investment schemes is standard practice in other countries. For example, all peer countries require such schemes to be managed by dedicated vehicles, primarily in order to protect the interests of small investors ${ }^{25}$. Chile has a legal vehicle for mutual funds management (administradora de fondos mutuos) that can be owned by banks, insurance companies or brokerage companies. Both Mexico and Spain also have specialized vehicles for mutual fund management (sociedad de inversion and sociedad de gestión de instituciones de inversión colectiva respectively) that can be owned by banks.

Figure 4: Size of Mutual Fund Industry in Selected Countries (2004)

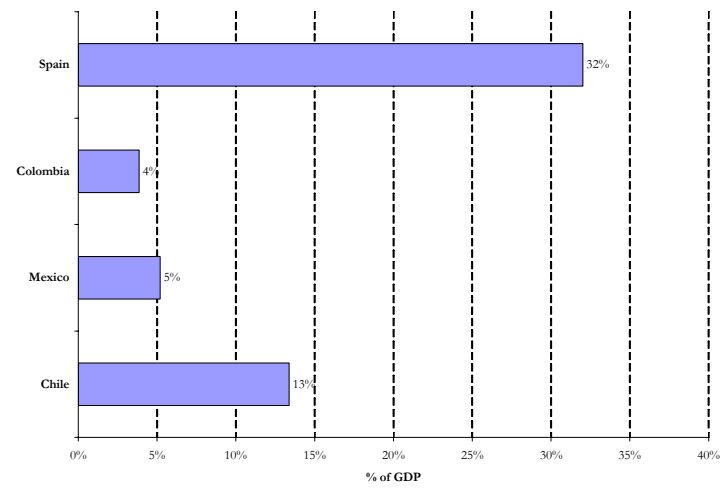

Source: Investment Company Institute, World Bank, Superintendencia Financiera, own analysis. Note: Figures for Colombia include FCO, FCE, FV and FI.

\footnotetext{
${ }^{25}$ For example, IOSCO (1996) states: "It is advisable that the manager of a CIS [Collective Investment Scheme] should be prohibited... from conducting any other business than that of a CIS in the CIS or in any portfolio. This requirement is necessary to prevent a conflict of interest between the business of the CIS and such other business".
} 
The benefits of this recommendation are potentially substantial and could encourage further development of this industry. Based on the experience of collective investment schemes in other countries, several benefits would arise from bringing the management of collective investment schemes 'under a single roof':

- avoidance of regulatory arbitrage and reduction of conflicts of interest - this is a critical consideration given the diverse activities of fiduciarias and comisionistas de bolsa (e.g. concurrent management of proprietary portfolio and third party funds), the lack of a comprehensive regulatory framework for checks-andbalances and internal controls (e.g. no independent Board of Directors or custodians ${ }^{26}$ ), and the concentration of all fund management functions (e.g. valuation, registrar services, back office etc.) within each provider

- further growth of this industry, whose size still lags other countries (see above Figure), via consolidation and greater profesionalization

- greater efficiency via scale economies - for example, the median FCO size as of end-2005 was about Col\$240 billion (equivalent to about US\$100 million), while the median FCE and FV size was only about Col\$36 billion and Col\$20 billion respectively ${ }^{27}$;

- more specialization leading to greater professionalization and better management of operational risks;

- greater market transparency in terms of costs of transactions and services.

However, implementation of this recommendation will not be trivial $^{28}$. On the regulatory side, important legal and regulatory changes would be necessary in order to introduce this reform. A Decree currently under preparation, which aims to greatly harmonize and strengthen the regulatory treatment for different types of collective investment schemes, would be a useful intermediate step in the reform process; however, international experience raises doubts as to whether the Decree can also resolve existing conflicts of interest without changes in market structure. On the industry side, collective investment schemes account for a significant part of the current business of many fiduciarias, which manage around 75 percent of such assets ${ }^{29}$, but not of comisionistas de bolsa. However, it is worth noting that these entities already organize their investment management business distinctly from other activities, while a migration to any new structure would need to take place gradually in order to ensure a smooth transition.

\footnotetext{
${ }^{26}$ In line with good international practice, custody services should be provided by third parties that are independent and unrelated to the fund manager.

${ }^{27}$ Another significant determinant of the current fragmentation and related small average fund size has been the strategy of the large financial conglomerates - for example, Grupo Aval controls at least 9 different entities (fiduciarias and comisionistas de bolsa) that offer collective investment schemes.

${ }^{28}$ An attempt to adopt a similar proposal in 2003 was abandoned after strong industry opposition.

${ }^{29}$ Even though FCOs and FCEs only account on average for 18 percent of total fiduciary assets ("activos fideicomitidos”), 40 percent of the fiduciarias' commissions (equivalent to around one-fourth of total revenue) are derived from their management.
} 
Table 10: Size and Ownership of Five Largest Collective Investment Scheme Providers (December 2005)

\begin{tabular}{lccc}
\hline & $\begin{array}{c}\text { Collective Investments under } \\
\text { Management (Col\$ billion) }\end{array}$ & Market Share & Ownership \\
\hline Fiducolombia & 2,980 & $17 \%$ & Grupo Sindicato \\
Suvalor & 1,640 & $9 \%$ & Grupo Sindicato \\
Fiduciaria Davivienda & 1,601 & $9 \%$ & Grupo Bolivar \\
Fiduvalle & 1,170 & $7 \%$ & Grupo Aval \\
Fiduciaria Bogota & 1,090 & $6 \%$ & Grupo Aval \\
\hline
\end{tabular}

Source: Superintendencia Financiera, own analysis.

Note: Collective investments include FCO, FCE, FPVs (only those managed by fiduciarias), FV and FI. Fondos mutuos vigilados are excluded.

\section{Specific Reform 3: Fiduciary Activities}

Recommendation: Allow banks to offer services currently provided by fiduciarias, with the exception of collective investment schemes. Law 45/1923 had permitted the provision of trust activities directly by banks, but it was not until Law 45/1990, which obliged the creation of stand-alone companies (fiduciarias), that this type of activity grew in importance. Fiduciarias are essentially responsible for managing/administering third party trusts/funds ("fideicomisos") ${ }^{30}$ that can be established for several reasons ${ }^{31}$. The Superintendencia Financiera classifies fiduciary activities into the following categories: inversión (FCO, FCE etc.), inmobiliaria (payments and collections for construction projects etc.), administración (payments and collections for other trusts such as those for inheritance, property, securitizations and restructured loans etc.), seguridad social (administration and investments of trusts/funds related to social security, including FPV), and garantía y otros (all others, including fiducia en garantía). The recommendation would allow banks - in addition to fiduciarias - to directly offer such services if they so wish, with the aforementioned exception of management of collective investment schemes ${ }^{32}$.

Fiduciarias are a relatively rare type of legal vehicle internationally. Even though the legal concept of a trust/fiduciary contract exists in other countries, fiduciarias have no direct counterparts (including in Chile, Mexico and Spain) and their application and

\footnotetext{
30 There exist three main types of fiduciary contracts in Colombia: fiducia mercantil (transfer of ownership and creation of autonomous trust for funds/goods, which is managed by the fiduciaria on behalf of the beneficiary), encargo fiduciario (the fiduciaria administers the funds/goods on behalf of the owner without any transfer of ownership or creation of autonomous trust) and fiducia publica (similar to encargo fiduciario but involving a public entity).

${ }^{31}$ These include, for example, collective investments (e.g. FCO, FCE) and other investment funds with "specific destination" (e.g. public pension funds), securitization vehicles (e.g. for securitizations of construction projects, bank loans, or of future cash flows of local/national government), construction / property development / infrastructure projects, restructured corporate and municipal loans (Laws 550/1999 and 617/2000), liquidation of private and public companies, administration of housing subsidies, inheritance and life insurance contracts, and collateral trusts ("fiducia en garantía”).

32 There might also be a few other fiduciaria activities that, based on good international practice, should not be provided by the banks - for example, management of securitization special purpose vehicles.
} 
interpretation are very different. Their activities are instead allocated to different types of entities - for example, banks are typically responsible for trust and custody services ${ }^{33}$, specialized fund management companies are responsible for collective investment schemes, while some other activities (e.g. payment of public pensions) are not normally associated with financial institutions. However, as can be seen in the Figure below, fiduciarias have proved quite successful in Colombia, potentially because they are perceived as a relatively efficient response to contract enforcement problems and general distrust concerns.

Figure 5: Evolution of Fiduciarias by Asset Type (1996-2005)

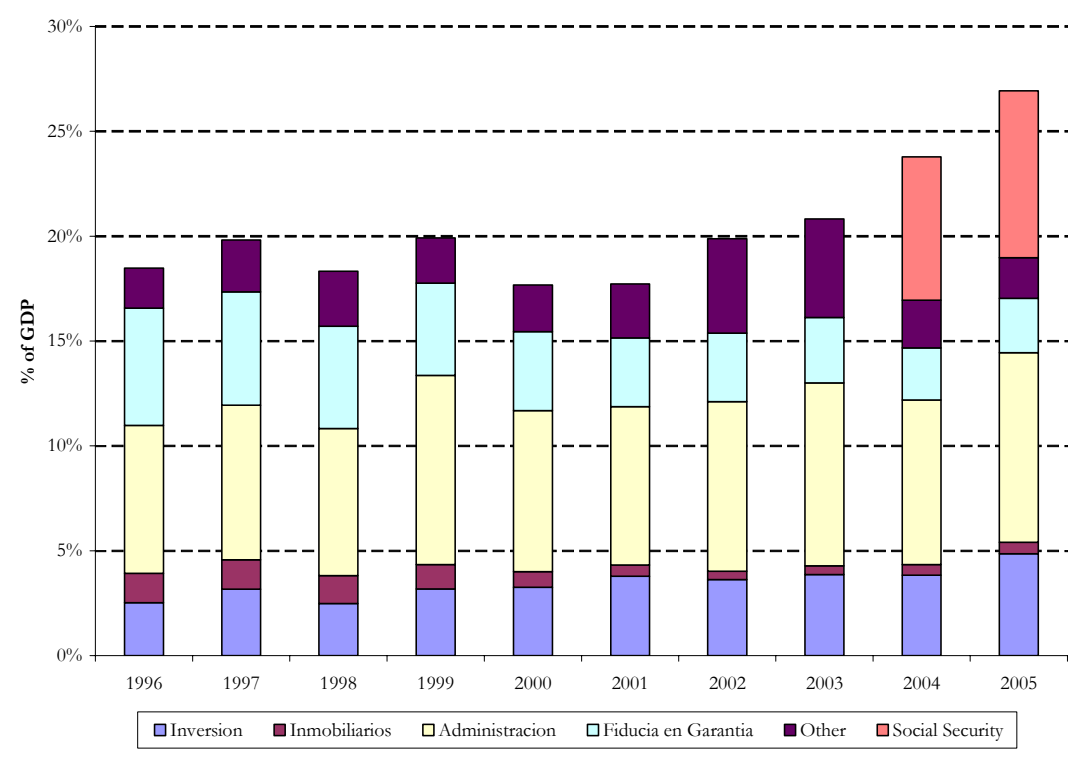

Source: Superintendencia Financiera, World Bank, own analysis.

This recommendation would allow market choice and greater efficiencies, but conflicts of interest should be addressed via a stronger prudential framework. The proposed reform would permit banks to choose whether to offer fiduciary activities directly, while it would allow niche players to continue operating in this market via fiduciarias. Assuming that some fiduciarias currently owned by financial groups are subsumed into the group bank, the main benefit of this reform would be greater operational efficiencies (i.e. similar to the leasing recommendation); these have to be weighed against the good experience and innovative products of stand-alone fiduciarias in recent years, although the final decision should be voluntary/market-driven and not imposed by regulation. Smaller banks might also decide to enter this market and provide greater competition by offering fiduciary services in-house. These benefits on balance likely outweigh the risks of additional conflicts of interest and explicitly extending the bank safety net to cover fiduciary activities. In particular, conflicts of interest primarily apply to collective investment schemes that are not part of this proposal. Some conflicts of interest that already exist ${ }^{34}$ could be exacerbated and would need to be addressed via a

\footnotetext{
${ }^{33}$ Mexico allows banks that are unrelated to the loan originating bank to manage the 'fiducia en garantía'.

${ }^{34}$ Potential conflicts of interest are apparent in the transactions between the fiduciaria and the rest of the financial conglomerate. For example, the fiduciaria typically manages the securitization vehicle and the
} 
stronger prudential framework ${ }^{35}$ - this is a necessary precondition for the successful implementation of this recommendation. With respect to extending the safety net, the lingering public perception (confirmed in practice during the 2002 mini-crisis) of the dependence of fiduciarias on their banks, renders unclear the validity of such a concern ${ }^{36}$.

Table 11: Size and Ownership of Five Largest Fiduciarias Excluding Investments (December 2005)

\begin{tabular}{lccc}
\hline & $\begin{array}{c}\text { Assets under Management } \\
\text { (Col\$ billion) }\end{array}$ & Market Share & Ownership \\
\hline Fiducolombia & 15,926 & $26 \%$ & Grupo Sindicato \\
Previsora & 9,120 & $15 \%$ & State-owned \\
Fidupopular & 4,013 & $6 \%$ & Grupo Aval \\
Cititrust & 3,999 & $6 \%$ & Citigroup \\
Fiduoccidente & 3,823 & $6 \%$ & Grupo Aval \\
\hline
\end{tabular}

Source: Superintendencia Financiera, own analysis.

Implementation of this recommendation should not be very difficult for the regulator or the industry. On the regulatory side, both bank permissible activities and the prudential framework need to be amended appropriately. On the industry side, much will depend on how different banks - especially those that belong to the large financial groups dominating this market (see Table above) - perceive the relative benefits and costs of absorbing their fiduciaria subsidiary ${ }^{37}$. However, given the dependence of many fiduciarias on their bank parents for many of their activities (e.g. sales, collections, back office), it is unlikely that the overall impact on the financial system will be significant.

\section{E. Specific Reform 4: Investment Banking - Banks, CFs and Comisionistas de Bolsa}

Recommendation A: Allow banks to offer all types of investment banking services, with the exception of long-term equity investments in the real sector. Banks are currently prohibited from offering such services - i.e. advisory/structuring, securities underwriting (except for sovereign debt) and brokerage, and equities trading - which are currently provided by CFs and comisionistas de bolsa. This recommendation would allow banks to also offer investment banking directly (with the exception of long-term equity investments in non-financial companies), but it would let them choose whether to provide such services in-house or via a specialized vehicle instead.

fiducias en garantía for loans originated by its group bank, while its 'sweep account' services (i.e. overnight placement of excess liquidity) for the trusts it manages are often invested in related funds.

${ }^{35}$ These include, for example, stronger corporate governance standards and greater transparency, or even the outright prohibition of certain transactions with other financial group entities.

${ }^{36}$ An additional, albeit questionable, risk stems from legal complications (i.e. confusion between third party and own funds) that could arise in case of bank insolvency; although this should not be a preoccupation in theory, it has been corroborated in practice in some countries.

${ }^{37} 21$ out of 28 fiduciarias, accounting for 80 percent of total fiduciary assets, were controlled by banks as of end-2005. 
The traditional separation between commercial and investment banking is fading internationally, although many banks prefer to offer the latter via a standalone securities market vehicle. As can be seen in the Table below, Chilean banks are allowed to engage in most investment banking activities, with the exception of trading and long-term investments in equity (a carry-over from the associated problems of the 1982 crisis). Mexican banks are not allowed to underwrite or trade equities, although (like in the EU) they can take long-term equity investment positions subject to strict concentration, related party and capital adequacy limits. In Spain and other EU countries, most investment banking services can be offered directly by banks but it is common practice for this type of business to be carried out by a securities subsidiary. However, even in such cases, the banks organize their business lines so that they can offer their clients the full gamut of investment banking services in an integrated fashion, regardless of the different legal vehicles that are performing different roles.

Table 12: Permissible Investment Banking Activities in Chile, Mexico and Spain

\begin{tabular}{|c|c|c|c|c|c|c|c|c|}
\hline \multirow[b]{2}{*}{ Permissible Activities } & \multicolumn{3}{|c|}{ Chile } & \multicolumn{2}{|c|}{ Mexico } & \multicolumn{3}{|c|}{ Spain } \\
\hline & Bancos & $\begin{array}{c}\text { Corredores de } \\
\text { Bolsa }\end{array}$ & $\begin{array}{c}\text { Agentes de } \\
\text { Valores }\end{array}$ & Bancos & $\begin{array}{c}\text { Casas de } \\
\text { Bolsa }\end{array}$ & Bancos & $\begin{array}{c}\text { Agencias de } \\
\text { Valores }\end{array}$ & $\begin{array}{c}\text { Sociedades de } \\
\text { Valores }\end{array}$ \\
\hline Institutional / High Net Worth asset management & $\bar{x}$ & $\bar{x}$ & $\bar{x}$ & $\bar{x}$ & $\bar{x}$ & $\bar{x}$ & $\bar{x}$ & $\bar{x}$ \\
\hline Cash management and payments services & $\mathrm{X}$ & & & $\mathrm{x}$ & & $\mathrm{x}$ & & \\
\hline Custody & $\mathrm{x}$ & $\mathrm{x}$ & $\mathrm{x}$ & $\mathrm{x}$ & $\mathrm{x}$ & $\mathrm{x}$ & $\mathrm{x}$ & $\mathrm{x}$ \\
\hline Trust / fiduciary services & $\mathrm{x}$ & $\mathrm{x}$ & $\mathrm{x}$ & $\mathrm{x}$ & $\mathrm{x}$ & $\mathrm{x}$ & $\mathrm{x}$ & $\mathrm{x}$ \\
\hline Foreign exchange trading - own account & $\mathrm{x}$ & $\mathrm{x}$ & $\mathrm{x}$ & $\mathrm{x}$ & $\mathrm{x}$ & $\mathrm{x}$ & & \\
\hline \begin{tabular}{|l} 
Derivatives trading - own account \\
\end{tabular} & $\mathrm{x}$ & $\mathrm{x}$ & $\mathrm{x}$ & $\mathrm{x}$ & $x$ & $\mathrm{x}$ & & $\mathrm{x}$ \\
\hline Sovereign debt underwriting (primary dealers) & $\mathrm{x}$ & $\mathrm{x}$ & $x$ & $x$ & $\mathrm{x}$ & $x$ & & $x$ \\
\hline Sovereign debt trading - own account & $\mathrm{x}$ & $\mathrm{x}$ & $\mathrm{x}$ & $x$ & $\mathrm{x}$ & $x$ & & $\mathrm{x}$ \\
\hline Corporate debt underwriting & $\mathrm{x}$ & $\mathrm{x}$ & $\mathrm{x}$ & & $\mathrm{x}$ & $\mathrm{x}$ & & $\mathrm{x}$ \\
\hline Corporate debt trading - own account & $\mathrm{x}$ & $\mathrm{x}$ & $\mathrm{x}$ & $\mathrm{x}$ & $\mathrm{x}$ & $x$ & & $x$ \\
\hline Equities underwriting & $\mathrm{x}$ & $\mathrm{x}$ & $\mathrm{x}$ & & $\mathrm{x}$ & $\mathrm{x}$ & & $\mathrm{x}$ \\
\hline Equities trading - own account & & $\mathrm{x}$ & Only listed stocks & & $\mathrm{x}$ & $\mathrm{x}$ & & $\mathrm{x}$ \\
\hline Advisory (M\&A, IPOs) and structuring services & $\mathrm{x}$ & $\mathrm{x}$ & $\mathrm{x}$ & $\mathrm{x}$ & $\mathrm{x}$ & $\mathrm{x}$ & & $\mathrm{x}$ \\
\hline Institutional brokerage ( $F / X$, debt, equity, derivatives) & $\mathrm{x}$ & $\mathrm{x}$ & $\mathrm{x}$ & Except equity & $\mathrm{x}$ & $\mathrm{x}$ & $\mathrm{x}$ & $x$ \\
\hline Retail brokerage ( $F / X$, debt, equity, derivatives) & F/X and debt & $\mathrm{x}$ & $\mathrm{x}$ & & $\mathrm{x}$ & $\mathrm{x}$ & $\mathrm{x}$ & $\mathrm{x}$ \\
\hline Private equity fund management & & & & $\mathrm{x}$ & $\mathrm{x}$ & $\mathrm{x}$ & & $\mathrm{x}$ \\
\hline Merchant banking / investments in the real sector & & $\mathrm{x}$ & Only listed stocks & $\mathrm{x}$ & & $\mathrm{x}$ & & \\
\hline Customer deposits (demand or savings accounts) & $\mathrm{x}$ & & & $\mathrm{x}$ & & $\mathrm{x}$ & & \\
\hline
\end{tabular}

Source: Own analysis based on information from relevant Superintendencies and Central Banks.

Equity investments in the real sector by Colombian banks should only be allowed when a comprehensive framework for consolidated supervision is adopted. In other countries (e.g. EU), equity investments in the real sector in the banking book (as opposed to the trading book) of banks are often allowed under strict prudential requirements. However, investing in real sector companies has historically been forbidden to banks (but not CFs) in Colombia. A strong argument can be made that such a measure remains necessary given the dominant presence of mixed-activity economic groups in Colombia's financial system, their often complex and non-transparent corporate structure, and the lack of a sufficiently comprehensive legal definition of an economic group for financial supervision purposes. Unless and until the two latter issues are resolved by the adoption of fully comprehensive laws, regulations and supervisory procedures (see General Reforms 2 and 4), the risk of extending the safety net to such activities by bringing them under the bank would be relatively high and would outweigh any potential benefits that could arise. In addition, the forthcoming Basel II Accord penalizes banks for such investments (especially for non-listed firms) by assigning them higher capital requirements; as a result, banks in other countries have been spinning off such activities in separate vehicles such as private equity funds. 
This recommendation would eliminate some barriers to efficiency and allow market choice, at the cost of increasing potential conflicts of interest. There is no special reason why banks should not be allowed to provide (at least some types of) investment banking services, and bringing those services under "the same roof" would create operational synergies. In fact, anecdotal evidence already suggests that most comisionistas that belong to banks are relatively smaller since some of their activities are instead undertaken by the parent bank itself (e.g. bond trading). In addition, to the extent that such a move encourages smaller banks to enter this market, it could also help to strengthen competition. The risk stems from the potential extension of the bank safety net and the conflicts of interest that could arise if investment banking services are provided by the same entity that offers other types of banking services. However, the overall size of this market remains small (see next paragraph) while, as described later in the paper (see General Reform Issue 2), prevention of conflicts of interests is not guaranteed in itself by the formal separation of legal vehicles that belong to the same financial conglomerate. This type of risk would be better mitigated by the adoption of strong regulations on firewalls that are complemented by effective enforcement - these are necessary preconditions for the adoption of this recommendation.

The ease of implementation of this recommendation is moderate, although its impact is not likely to be substantial. As far as the authorities are concerned, the relevant legal changes are specific and fairly straightforward, but regulation and supervision will need to be amended accordingly. From the point of view of the industry, the implementation process should not pose significant problems, as financial conglomerates that are already providing these services will need to decide whether to adopt a different business model for investment banking as part of their broader strategy. Although this recommendation might spur the growth of investment banking, it is not expected to have an important effect in the short term. There are no available figures for the overall size of this industry, but most of the revenue stems from government securities trading that is already undertaken by the banks. By contrast, total primary and secondary equity and corporate bond issuance has been relatively small in recent years (around 20-25 issues annually, half of them by financial institutions).

Recommendation B: Develop a full-fledged investment banking vehicle by strengthening Comisionistas de Bolsa and eliminating Corporaciones Financieras. There are currently two types of legal vehicles (CFs and comisionistas) that have some overlap in their investment banking activities, but each of which in itself does not constitute a comprehensive investment banking license. The recommendation would allow the creation of the latter by extending the range of permissible activities of comisionistas to include those currently undertaken by CFs (for example, merchant banking and project/structured finance). The figure of CFs would be eliminated and existing ones could be converted into comisionistas or subsumed under the group bank.

There are several ways to achieve a comprehensive investment banking vehicle, but market developments suggest that comisionistas are a good starting point. In particular, there are numerous options - each with its own pros and cons - of designing a 
'pure' investment bank vehicle starting from the current situation in Colombia ${ }^{38}$. In practice, however, the relative importance of CFs has decreased substantially over time ${ }^{39}$. As can be seen in the Tables below, there are only 2 remaining CFs (down from 24 in 1995) that account for 2 percent of GDP. The bulk of the securities activity is currently shared between banks (mainly sovereign debt) and comisionistas (equities and corporate debt).

Table 13: Size and Ownership of Corporaciones Financieras (February 2006)

\begin{tabular}{lccc}
\hline & $\begin{array}{c}\text { Total Assets } \\
\text { (Col\$ billion) }\end{array}$ & Market Share & Ownership \\
\hline $\begin{array}{l}\text { Corfivalle } \\
\text { Colcorp }\end{array}$ & $\begin{array}{c}4,986 \\
401\end{array}$ & $\begin{array}{c}93 \% \\
7 \%\end{array}$ & $\begin{array}{c}\text { Grupo Aval } \\
\text { Grupo Sindicato }\end{array}$ \\
\hline
\end{tabular}

Source: Superintendencia Financiera, own analysis.

Table 14: Size and Ownership of Five Largest Comisionistas (2005)

\begin{tabular}{lccc}
\hline & $\begin{array}{c}\text { Total Turnover } \\
\text { (Col\$ trillion) }\end{array}$ & Market Share & Ownership \\
\hline Interbolsa & 140 & $18 \%$ & Independent \\
Inversionistas de Colombia & 77 & $10 \%$ & Independent \\
Correval & 71 & $9 \%$ & Independent \\
Suvalor & 64 & $8 \%$ & Grupo Sindicato \\
Alianza & 59 & $7 \%$ & Independent \\
\hline
\end{tabular}

Source: Superintendencia Financiera, own analysis.

Note: Size is based on annual equity and debt turnover (both for third parties and for own account) for 2005.

In addition to eliminating the figure of CFs, this recommendation would necessitate the regulatory revision and upgrading of comisionistas de bolsa. In practice, comisionistas actually have three different levels of license, each with its own range of permissible activities (brokerage only, broker-dealer, broker-dealer plus foreign exchange intermediation) and related minimum regulatory capital level. Incorporating some of the aforementioned additional permissible activities will likely require a revision of the current three-level arrangement and stronger overall prudential requirements ${ }^{40}$. In addition, there might be a need to differentiate their names in order for the public to clearly distinguish among the different license levels - for example, by calling them comisionistas de bolsa versus sociedades de bolsa versus sociedades de valores.

\footnotetext{
38 These include, for example, extending permissible activities of CFs and reducing those of comisionistas to brokerage; extending permissible activities of CFs and comisionistas so that both of them could provide investment banking services; and creating an entirely new figure for investment banking, thereby eliminating the need for CFs and reducing comisionistas to brokerage.

39 The CFs have not been helped by their historical emphasis on long-term financial intermediation (originally funded by international financial institutions) that is now unprofitable because of the lack of access to cheap funding.

40 These would build upon the 2003 reforms introduced by the SV, which strengthened regulatory capital requirements and upgraded the required professional capacity (including risk controls) of comisionistas.
} 
The practice in other countries varies widely on this issue, but such vehicles are generally more closely aligned to the figure of comisionista de bolsa. As can be seen in Table 11 above, both Chile and Spain have two types of securities firms (partly for historical reasons) while Mexico only has casas de bolsa. However, it is worth noting that the firms in all three countries (and the EU) are much closer to securities markets than to financial intermediation, being in this sense like comisionistas rather than CFs.

There are several benefits to having a full-fledged 'pure' investment bank, but neither the ease of implementation nor the overall impact is likely to be high, at least in the short term. Potential benefits include a more credible and visible investment banking figure that could help stimulate the market, and potentially greater competition. With respect to risks, care should be taken for a smooth exit process for CFs and upgrading procedure for comisionistas, as well as to ensure that there will be no regulatory arbitrage between banks and comisionistas when undertaking similar investment banking activities. Implementation will likely not be easy for the authorities and the industry, since the recommendation requires a substantial revision of the current framework. Given the aforementioned size and allocation of the investment banking 'pie', its overall impact would likely remain relatively small in the short term.

Recommendation C: Allow all credit institutions to finance the acquisition of real sector companies, subject to standard prudential requirements and credit procedures. For historical reasons, such debt financing is forbidden to banks (article 72 of the EOSF and Carta Circular 143/2003), and it is even considered an offence in the Criminal Code (article 316). This recommendation would align Colombia to the practice in other countries by permitting acquisition financing and subjecting it to standard prudential requirements (large exposures, capital adequacy rules etc.) and credit assessment policies and procedures.

The reform would stimulate corporate acquisition activity and level the playing field across banks, although it requires amending high-rank regulations. In particular, increased financing possibilities could encourage the development of a more active domestic corporate acquisitions market (such a market is currently very small and hence the short-term impact would be minimal). It would also help domestic banks that are currently at a competitive disadvantage vis-à-vis foreign banks, because the latter can finance acquisitions of real sector companies offshore. With respect to risks, there is a perception that the reform could encourage financial speculation, but the presence of appropriate regulatory and supervisory practices (which did not exist in the past) mitigates such a concern. Implementation should not pose significant problems for the industry or for supervisors, although it requires the amendment of high-rank regulations like the EOSF and the Criminal Code.

\section{F. Specific Reform 5: Sociedades de Capitalización}

Recommendation: Eliminate the vehicle of Sociedades de Capitalización. Sociedades de capitalización were created by law 66/1947 and were a popular form of 
financial savings prior to the 1990s. A client investing in "títulos/cedulas de capitalización” would essentially be required to open an account for at least one year in exchange for participation in periodic lotteries in which he could gain a multiple of his own contributions to the account, as well as the opportunity to borrow against those "títulos" and to receive a (low) return for his investment. The sociedades de capitalización would in turn invest these funds in debt and equity securities, subject to the same investment regime as insurance companies. The recommendation would eliminate this type of vehicle by obliging existing firms to convert themselves into (or be absorbed by) other types of financial intermediaries.

Table 15: Size and Ownership of Sociedades de Capitalización (December 2005)

\begin{tabular}{lccc}
\hline & $\begin{array}{c}\text { Total Assets } \\
\text { (Col\$ billion) }\end{array}$ & Market Share & Ownership \\
\hline Bolivar & 493 & $33 \%$ & Grupo Bolivar \\
Capitalizadora Colpatria & 419 & $28 \%$ & Mercantil Colpatria \\
Cedulas Colon de Cap. Colseguros & 275 & $18 \%$ & Allianz \\
Capitalizadora Suramericana & 258 & $17 \%$ & Grupo Sindicato \\
Capitalizadora Colmena & 62 & $4 \%$ & Fundacion Social \\
\hline
\end{tabular}

Source: Superintendencia Financiera, own analysis.

The perceived benefits of this recommendation outweigh the costs, although the impact on the financial system is very small. In particular, sociedades de capitalización are an inefficient vehicle for savings given their low absolute returns (often negative in real terms); the existence of the lottery mechanism has been their biggest attraction. Their elimination would permit the channeling of those resources to the banking sector, although there is a minor risk that the relevant population segment (lower- to middleincome) might instead decide to marginally reduce its financial savings if they are not offered financial products that they consider attractive. However, the lack of flexibility and product innovation, combined with the development of more efficient instruments by the financial system, has already led to the progressive decline of these entities and few inflows of new business. As can be seen in the above Table, there are currently five sociedades de capitalización whose total assets amount to around Col\$1,500 billion or US\$650 million (0.5 percent of GDP or 1.7 percent of bank deposits). Implementation of this recommendation would be relatively easy for regulators given their small size and relative 'isolation' with the rest of the financial system ${ }^{41}$, while a carefully managed transition path for existing client contracts (some of which are set to expire within 8-9 years) would facilitate the exit process of these entities.

\section{G. General Reform 1: Legal Framework}

Recommendation: Review and revise the legal framework for the financial system in terms of hierarchy, consistency and breadth of coverage. A reform effort to

${ }^{41}$ In fact, two of the five companies are apparently in the process of exiting the industry. 
rationalize and simplify the legal framework began in 1990 with the creation of the EOSF, but the desired objectives were not fully met for a variety of reasons (see below).

There is a significant difference in Colombia between theory and practice in the legal concept of vertical hierarchy. Colombia, like other countries following the Continental or Napoleonic model, has a legal framework based on written law and a clear vertical hierarchy between different types of regulations ${ }^{42}$. This legal concept has two main implications: a lower-rank regulation cannot contravene higher rank regulations, but can only complement them on a more detailed or specific basis; and a subject must be regulated according to its relative importance, both in terms of the procedures and the bodies issuing it. However, even though the system is theoretically clear and effective, practice can be a different issue. Anecdotal evidence suggests that a common problem is that lower-rank regulations can 'over-interpret' higher-rank ones, thereby usurping or misappropriating legal powers and creating legal uncertainty that can only be resolved following strict and lengthy court procedures. The opposite case is also true, whereby higher-rank regulations (such as, for example, the ones found in the EOSF) get into too much detail and thereby 'invade' the scope of lower-rank ones. Although this latter issue should not be a major problem in theory, it can be quite important in practical terms because it complicates the task of updating regulations to financial system developments since it requires longer procedures and the approval of higher bodies (e.g. Congress).

Although the EOSF was devised as a legal mechanism to clarify and give consistency to the financial regulatory framework, it suffers from complexity and lack of a clear structure. The EOSF was issued in the form of Decree 663/1993 ${ }^{43}$, and its intention was to systematically condense existing financial system regulations into a single body. Given the way it was produced, the EOSF has the rank of a law (in technical terms, the name is "Decreto-Ley") and all reforms to it must therefore be made by Congress, as the faculties given to the President were on an extraordinary and specific time basis. However, the EOSF essentially put together existing regulations ("recopilación") rather than analytically create new ones based on existing regulatory principles and objectives ("compilación"). As a result, the EOSF is actually comprised of very different regulations with unclear structure, not only in terms of the regulated issues but also in terms of the different legal ranks that should be used for different subjects and levels of detail and importance. This has impeded legal certainty and a clear understanding of the "rules of the game" by market participants ${ }^{44}$ and sometimes even by regulators. In addition, updating the EOSF has become an increasingly complex and lengthy process even for minor adaptations, given the excessive detail of many of the regulations contained in it. This could create situations of legal obsolescence and regulatory gaps, where market participants assume legal risk if they undertake what they should be allowed to do or where regulators do not have the appropriate legal instruments

\footnotetext{
${ }^{42}$ The Constitution forms the supreme regulation and establishes the master lines of the legal system; these are further developed by Laws, which are in turn put into practice through Decrees; finally, the Decrees are operationalized via Resolutions, Circulars and Instructions.

${ }^{43}$ Congress extraordinarily authorized the President of the Republic via Law 45/1990 to issue the EOSF.

${ }^{44}$ Anecdotal evidence suggests that different market participants interpret the same regulation differently for example, the concept of "delegación de profesionalidad".
} 
to perform their functions. The problems surrounding the EOSF are progressively becoming worse as the volume of regulations increases - particularly with the forthcoming incorporation of securities markets law as a result of the merger of the two Superintendencies - and changes to them are prepared on a piece-meal basis.

Practical and tested solutions to this problem can be found in other countries with a similar legal model. In particular, the most common and effective response would be to organize a real compilation process ("compilación") where the different issues to be regulated can be considered in a structured manner. This implies the creation of so-called financial "Ley Marco" or "Ley de Bases", whereby only the general principles are stated, and are accompanied by Decrees, Resolutions and Circulars with the required detail at each level. This regulatory package should be addressed in a uniform and orderly way to ensure that no inconsistencies are produced. An analytical exercise should be undertaken prior to this process in order to validate the need for this reform and to detect the main inconsistencies.

The implementation of this reform is difficult and fraught with risks, but it is clearly beneficial and any further delays would merely exacerbate the magnitude of the problem. Greater legal certainty and understanding by market participants, as well as faster and better updating of the legal framework to economic and financial changes going forward, are the main benefits of this recommendation. Possible risks stem from a revision process that is not well controlled, thereby resulting in unwanted changes to the substance (as opposed to the form) of regulation. However, this is likely the right time to undertake this exercise: the creation of the new Superintendencia Financiera obliges the inclusion of securities markets-related regulation in the EOSF, while any further delays would merely exacerbate the magnitude of the problems. Given its complex nature, implementation is likely to be difficult for regulators and supervisors ${ }^{45}$; by contrast, the implementation effort by the industry would be much easier. Finally, while there should in theory be no direct impact on the financial system in terms of substance, improving legal certainty / understanding and allowing a smoother legal updating process would be an important benefit of this recommendation.

\section{H. General Reform 2: Prevention of Conflicts of Interest}

Recommendation: Review, revise and clarify the existing legal and regulatory framework for the prevention of conflicts of interest. This can be achieved by reviewing and amending, as necessary, existing firewalls (e.g. exposure limits, "chinese walls", Board of Directors participation etc.) and shared activities within a financial firm and - in the case of financial conglomerates - between different group companies (e.g. common front office, infrastructure, client databases etc.).

Although formal separation of activities across and within firms can help to reduce conflicts of interest, this measure by itself is not enough. Historically, one of

\footnotetext{
${ }^{45}$ The creation of a Technical Legal Team would likely be necessary, whose objective would be to restructure the current regulations but not amend their content (unless required by other proposed reforms).
} 
the main reasons for developing Colombia's financial system based on separated, specialized legal vehicles has been the prevention of conflicts of interest. However, experience (including the 1998-99 crisis and the mini-2002 TES crisis) has shown that this approach is more formal than substantial, especially with the development of financial conglomerates under a common control and decision-making process. Regulations for the prevention of conflicts of interest cannot therefore be primarily based on formal criteria like the separation of businesses between companies and the appointment of different professionals for each one, but rather via an adequate set of relevant regulations.

In the case of Colombia, there are two major problems with regulations covering conflicts of interest. Firstly, such regulations (as recorded in the EOSF) appear fragmentary, with varying levels of detail depending on the type of financial institution, and do not fully address all the relevant issues of substance (e.g. "Chinese walls" between certain activities within institutions, sharing of client databases across institutions, nature of prudential framework and supervisory responsibilities vis-à-vis outsourcing providers etc.). Secondly, anecdotal evidence suggests that the understanding and interpretation of these regulations differs across individuals and companies, resulting in the adoption of different policies - for example, the extent to which certain services (e.g. Treasury, legal, accounting etc.) can be shared across financial entities of the same group via Service Level Agreements and under what conditions.

Good international practice points to the development of regulations that clearly lay out a set of general principles covering the prevention of conflicts of interest. This would require regulations formulating general principles regarding the prevention of conflicts of interest, with clear rules about which activities and conduct can be considered permissible and how. A substance-over-form principle should be applied in this context in order to avoid excessively formal, over-detailed or incomplete approaches. A different but related issue that should also be clarified in this process is the one related to outsourcing and the delegation of responsibilities ("delegación de profesionalidad"), which is based on the idea that there exist 'core' financial activities that cannot be transferred / delegated to other companies as that would imply the transfer of authorization for that activity. In the case of Colombia, such activities currently include fund management, which therefore has to be undertaken in-house. The two issues are related in case where outsourcing is conducted between companies of the same financial conglomerate, where existing conflicts of interest can be exacerbated.

It has also become good international practice to promote self-regulation by companies and groups in a context of transparency and public disclosure. The prevention of conflicts of interest cannot be based exclusively on external regulations, but must also provide market-based incentives for financial companies and groups to establish and enforce their own codes of conduct, allowing more detailed rules to be formulated that adjust the external general principles to the specific circumstances of each case. Transparency and public disclosure of these codes of conduct can be very helpful in order to convince market participants and the general public that conflicts of interest are effectively and professionally addressed. 
While the benefits of this recommendation are clear, the implementation process will not be easy. In particular, a detailed review and revision of existing regulations on this topic is required, which would in turn lead to changes in the way that the industry operates. However, greater legal certainty, transparency and understanding by market participants will ensure the consistent application of rules, potentially allow greater operational efficiencies (depending on the extent that outsourcing is allowed) and help to mitigate conflicts of interest. Potential risks include a revised framework that remains formalistic, leaves important gaps or is not properly enforced. Although a significant direct impact on the financial system as a result of this recommendation is not expected, greater market integrity and consistency in the application of the rules can have a potentially important indirect positive effect.

\section{General Reform 3: Financial System 'Perimeter'}

Recommendation: Review and revise the regulations defining reserved financial activities that are subject to supervision and the entities that could perform them. Colombian regulations consider reserved financial activities to be those that only authorized financial institutions are allowed to perform. However, these activities are defined narrowly, thereby leaving room for non-financial institutions to offer potentially similar activities that are not regulated. This recommendation would revise and broaden the definition to ensure consistency and appropriateness of reserved financial activities.

The current definition of 'reserved' financial activities in Colombia is fragmented across different types and hierarchies of regulation. The main ones are:

- article 335 of the Constitution (“Constitución Política de Colombia”), which states that financial, insurance and exchange market-related activities related to the collection and use of general public financial resources are considered of public interest and, as such, subject to previous public authorization;

- article 316 of the Criminal Code, which addresses the situation when public deposits are collected without being administratively authorized;

- articles 108 and 109 of the EOSF, which prohibit individuals and companies to perform activities that are exclusive to authorised financial institutions, to advertise as financial companies without having been authorised as such, and to use the term "ahorros" (savings);

- Decree 1997/88, which prohibits the use of names of financial authorised institutions to other companies.

As can be deduced, the definition of the financial system is mainly based on the authorized institutions that form it and on the exclusiveness of the narrowly defined activities that they undertake. This implies that the system does not have very clear borders, and there are practical examples where commercial, non-financially supervised companies are performing activities that could be considered (partly or exclusively) the prerogative of regulated financial institutions. Some of the main examples include: 
- "consorcios comerciales" / "autofinancieras" - these companies, which are made up of a few partners, collect funds from the general public in order to finance their car purchases;

- "cooperativas de ahorro y crédito" - these companies are fairly similar in terms of their activities to regulated financial cooperatives;

- funeral homes and other companies are offering "planes exequiales" (burial plans), which represents a form of an insurance contract that is also offered by regulated insurance companies;

- "afianzadoras" and other companies are offering "seguros de arrendamiento" (guarantee of rent payments for office rental), which represents a form of an insurance contract that is also offered by regulated insurance companies;

- "cambistas" (individual foreign exchange brokers) handle foreign exchange intermediation and remittances and are supposedly registered with the authorities, but they perform similar activities to regulated "casas de cambio".

It is worth noting that some of these companies are supervised by non-financial government bodies (e.g. "Superintendencia de Sociedades" and "Superintendencia de Economía Solidaria") under a different set of rules and regulations. At the same time, there are also companies that have been historically subject to financial regulation and supervision with relatively little justification, such as bond warehouses ("Almacenes Generales de Depósito") and insurance and reinsurance brokers.

There are at least three main problems stemming from an unclear financial system 'perimeter'. Firstly, there is the potential for the financial activities of unregulated companies to pose risks to the financial system and undermine financial stability; this is an important consideration, particularly given that the general public is unaware of such risks. Secondly, scarce supervisory resources are allocated to companies currently within the 'perimeter' for little apparent reason, which is a case of overregulation/supervision. Thirdly, there can be unfair competition between commercial companies and financially regulated companies that are subject to onerous prudential requirements, which introduces markets distortions and perverse incentives.

The recommendation seeks to better clarify the 'perimeter' of the financial system. As in other countries, this would involve describing more generally the type of activities that should be considered as exclusive and subject to financial authorization and supervision, irrespective of the specific names and descriptions used. Financial institutions should also be defined on this basis, specifying for each of them the statutory characteristics and type of permissible activities they can perform. In order to achieve this objective, legislation needs to be in place that clearly states the rules at the required level (i.e. Law for the main principles, and Decrees, Resolutions and Circulars for the necessary technical details and instructions) without gaps or ambiguities that could be used to distort the playing field. Effective sanctions and disciplinary measures should also be in place to ensure enforcement and compliance with the regulations, including for any identified illegal financial practices. In the case of Colombia, maintaining a so-called 'para-financial system' could also be feasible and potentially desirable. This refers to situations where certain activities and companies have some financial components, but are not enough in type or importance to classify them within the 'perimeter' in a strict 
sense. These companies could be subject to minimal relevant regulation and supervision, but this would be delegated by agreement to other government supervisory bodies. Clear and effective regulations and coordination procedures across supervisors would need to be in place for this arrangement to succeed.

The perceived benefits of this reform exceed the likely risks, but implementation will not be easy. The main benefits would be the promotion of financial stability, reduction in regulatory arbitrage and unfair competition, and increased protection of financial system users. The main risk would be the implementation of an inadequate or excessively formalistic or burdensome regulatory framework, which could create new opportunities for regulatory arbitrage or introduce additional and unnecessary supervisory burden. Due care should be taken in this sense of the legal hierarchy in order to avoid introducing in the law any interpretation criteria or detailed rules that should be part of lower-ranked regulations. Implementation of this reform by regulators and supervisors will likely not be easy given the technical requirements and based on international experience $^{46}$, while the implementation needs and related impact on the industry (market practices, pricing etc.) - while positive - are difficult to estimate a priori since they greatly differ by type of financial activity and/or company.

\section{J. General Reform 4: Financial Conglomerates}

Recommendation A: Give financial supervisors the right to presume whether a company is related to a financial group. This reform would address existing legal gaps that hamper the comprehensive supervision of mixed-activity financial conglomerates (see below). It would imply a more effective approach that gives supervisors the right to presume "iuris tantum" under certain broad criteria whether (financial or non-financial) companies form part of the same financial conglomerate, thereby shifting the onus of proof to the group itself.

Colombia does not have a sufficiently comprehensive legal definition of an economic group for financial supervision purposes, which creates potentially important systemic risks. The legal definition of an economic group, which is based on the Commercial Code (as amended by Law 222/1995) and supporting secondary regulation ${ }^{47}$, allows the Superintendencia Financiera to categorize financial conglomerates and require their consolidation for certain reporting and prudential

\footnotetext{
${ }^{46}$ The case of the European Union could be illustrative and helpful in this sense, since significant efforts had to be made in order to build the Single Market and create the European Financial Passport from a starting point of different financial systems, concepts and institutions.

${ }^{47}$ For example, Decree 2360/1993 (credit limits with related parties), Decree 2649/1993 (accounting rules), Circular 100/1995 (main accounting and financial requirements for credit institutions), Superintendencia de Sociedades Circular 030/1997 (reporting and prudential requirements for economic groups), Superintendencia de Valores Circular 002/1998 (consolidated accounting and financial disclosure by registered securities issuers), Decree 1720/2001 (minimum capital adequacy ratios) and Law 795/2003 (monitoring and on-site supervision of entities that are not under the direct control of the Superintendencia Bancaria but meet the presumptions required for consolidation).
} 
purposes $^{48}$. However, there remain important legal gaps covering the definition of a financial conglomerate (i.e. presumption of subordination or 'dominant influence') and the scope and conduct of consolidated supervision (e.g. development of a comprehensive and consistent risk assessment methodology) that do not allow supervisors to fully 'capture' an economic group. For example, in cases where shareholdings are below 50 percent but there is presumption of subordination, commonality of purpose and management must be proved for a company to be deemed to belong to an economic group. A narrow interpretation of this rule has historically allowed the two main economic groups to argue successfully that certain companies do not form part of them, impeding the supervisor from 'capturing' the entire group ${ }^{49}$. This exposes the financial system to vulnerabilities stemming from the presence of financial conglomerates that are not adequately addressed by financial regulation and supervision ${ }^{50}$.

International experience shows that supervisors must be empowered with a set of legal presumptions in order to be able to effectively determine a financial conglomerate's perimeter. Experience has shown that commercial legal frameworks for economic groups tend to be insufficient to address financial conglomerates given their complexity and importance. In particular, the emphasis of financial supervisors is not solely on knowledge of the ultimate conglomerate controller(s), but also on the relationships and inter-dependence between group companies in order to understand group-level sources and levels of risk and solvency. As such, some countries have adopted specific regulations for the determination of financial conglomerates that supersede Commercial Code rules (for example, Chile ${ }^{51}$ and Spain). Moreover, financial supervisors have been progressively entitled to presume links between companies in terms of control and influence, giving them the power to define the perimeter of the financial group and thereby shift the burden of proof.

Recommendation B: Introduce legislation that would inhibit authorization for complex and/or non-transparent financial group structures which cannot be supervised properly. This recommendation would introduce a regulation that permits the supervisory authorities to reject or withdraw the license of those financial institutions that form part of a financial group that is impossible to supervise effectively because of having a complex and/or non-transparent corporate structure based on specific criteria that would need to be determined.

\footnotetext{
${ }^{48}$ These requirements do not include consolidated minimum capital adequacy requirements for the entire group, which currently apply at the level of individual credit institutions and the bank holding company.

${ }^{49}$ For example, Grupo Aval currently consolidates its financial sector activities under 3 different financial groups for supervisory purposes (i.e. Banco de Bogota, Banco Popular and Banco de Occidente).

${ }^{50}$ A typology of vulnerabilities created by the presence of financial conglomerates in a financial system can be found in Joint Forum publications and in Stephanou C. (March 2005). These include excessive leverage or multiple gearing, inconsistent regulatory treatment and incomplete coverage, financial and psychological contagion, and distorted competition.

${ }^{51}$ Article 84 of the General Banking Act in Chile states: "Corresponderá a la Superintendencia determinar, mediante normas generales, las personas naturales o jurídicas que deban considerarse vinculadas a la propiedad o gestión del banco... El hecho de que sea deudora de un banco una sociedad constituida en el extranjero, entre cuyos socios o accionistas figuren otras sociedades o cuyas acciones sean al portador, hará presumir que se encuentra vinculada para los efectos de este número".
} 
Figure 6: Stylized Structure of Domestic Mixed-Activity Conglomerate

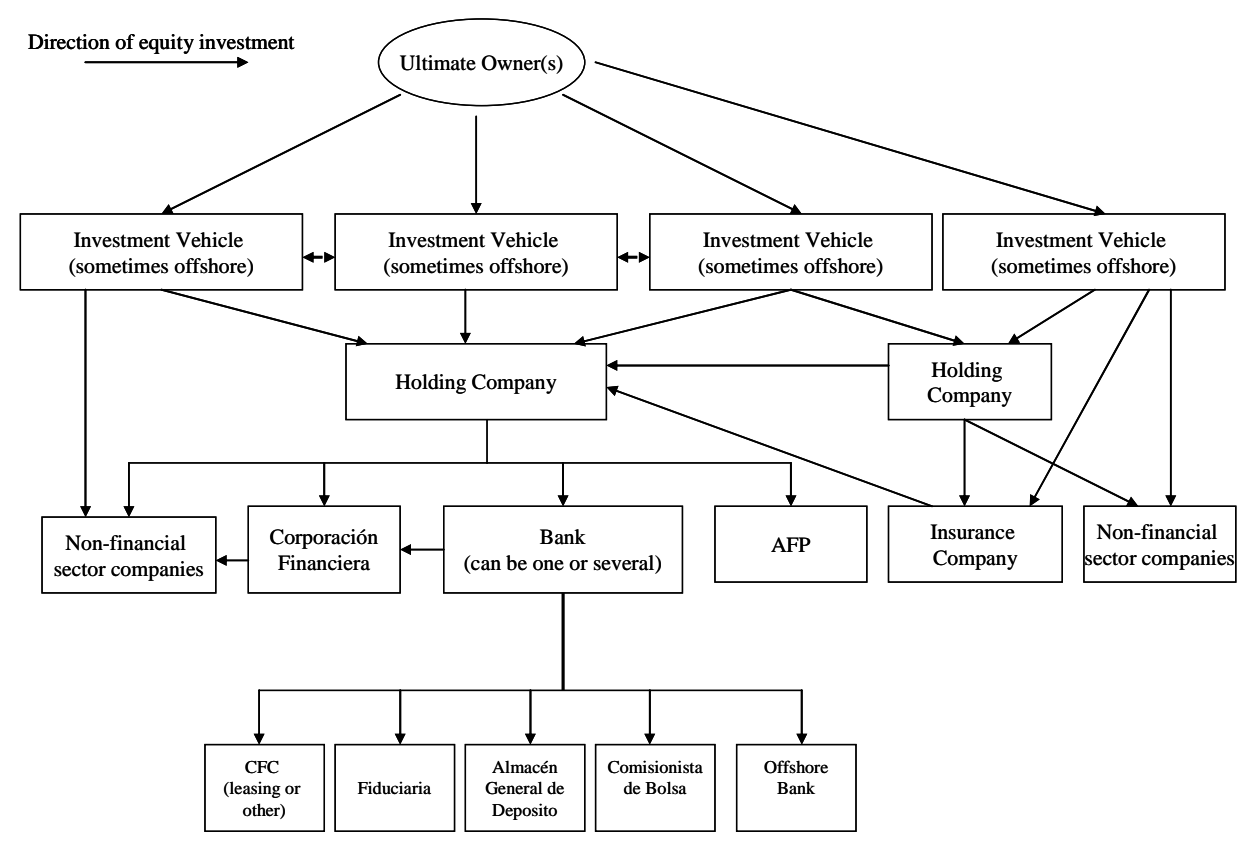

Consolidated supervision in Colombia is hindered by the complex and nontransparent corporate structures of some domestic mixed-activity financial groups. The historical rationale for mixing commercial and financial companies (e.g. benefits of intra-group financing and vertical integration etc.), the need for multiple institutional vehicles to undertake different activities, the restrictions on equity investments for certain financial institutions and other reasons (e.g. tax, security, control) have encouraged the proliferation of complex organizational structures. As can be seen in the Figure above, these tend to include several holding companies controlled via 'shell' investment vehicles (often offshore) by their ultimate owner(s). Banking- and securities-related activities tend to be concentrated under the bank holding company, while other financial (especially insurance) and real sector activities are provided through holdings above and/or parallel to the bank. The corporate structures differ among Colombia's largest financial conglomerates, ranging from a single holding company for all financial institutions of an economic group (e.g. Grupo Sindicato) to a more complex pyramidal structure of investment cross-holdings (e.g. Grupo Aval). There is currently no regulatory requirement for the creation of a separate financial holding company that would assemble together the different financial institutions of mixed-activity economic groups.

International experience has shown that financial supervisors must be empowered to reject structures that are difficult to supervise effectively. Group structures can be very complex for a variety of reasons, ranging from pure market and technical considerations to the relative unwillingness by certain groups to fully disclose their real situation. While the aforementioned market orientation principle would permit a variety of corporate structures, supervisors are responsible by law to effectively supervise the financial system and must therefore be granted the legal powers to properly undertake 
their role. For example, following the BCCI crisis, EU regulators have introduced a law that allows supervisory authorities to reject or withdraw the license of those financial institutions that form part of a financial group that is impossible to supervise effectively because of having a complex and/or non-transparent corporate structure ${ }^{52}$.

Both reform proposals would greatly facilitate effective supervision of mixedactivity financial conglomerates, although implementation will not be easy. The main benefit would be greater transparency of financial conglomerate structures, allowing a more effective application of existing prudential requirements (e.g. large exposures, related party lending, capital adequacy etc.) and understanding of the systemic risks and impact on the bank safety net. The main risk of the proposed reforms is related to overregulation, i.e. if supervisors exert their powers in a too subjective or intrusive manner. Even though there is currently a need to fully develop appropriate processes, information systems and procedures for consolidated supervision by the Superintendencia Financiera, implementation of the proposed reforms would help rather than hinder such efforts. There are theoretically no implementation considerations for the industry (but likely strong resistance from the affected parties). Although the proposed reforms' impact on efficiency is uncertain depending on how groups respond by changing their corporate structure, its main impact would likely be reduced systemic risk stemming from better transparency and disclosure of financial conglomerates.

Implementation of these reforms would also pave the way for a more flexible structure of financial groups. In particular, current regulations allow insurance companies to own banks (but not vice versa), and banks to control comisionistas, fiduciarias, CFCs and CFs (but not vice versa). A more level playing field would allow greater market choice and the proliferation of different organizational structures, which could potentially increase efficiency. However, this asymmetry in regulatory treatment should only be lifted once existing problems with the current structure are addressed, i.e. when the perimeter of financial conglomerates is well-defined and effective consolidated supervision is adopted.

\footnotetext{
${ }^{52}$ EU Directive 2000/12/CE, which incorporates the previous legislation on this topic, states: "Los Estados miembros pueden, además, denegar o retirar la autorización bancaria cuando consideren que la estructura del grupo es inadecuada para el ejercicio de las actividades bancarias, en particular, porque éstas no podrían supervisarse de forma satisfactoria. Las autoridades competentes disponen, a este efecto, de los poderes señalados en el párrafo... con vistas a garantizar una gestión saneada y prudente de las entidades de crédito... Cuando existan vínculos estrechos entre la entidad de crédito y otras personas físicas o jurídicas, las autoridades competentes concederán la autorización únicamente si dichos vínculos no obstaculizan el buen ejercicio de su misión de supervisión. Las autoridades competentes también denegarán la autorización cuando el buen ejercicio de su misión de supervisión se vea obstaculizado por las disposiciones legales, reglamentarias o administrativas del Derecho de un tercer país, aplicables a una o varias de las personas físicas o jurídicas con las que la entidad de crédito mantenga vínculos estrechos, o por problemas relacionados con su aplicación”.
} 


\section{Conclusions and Proposed Roadmap}

\section{A. Conclusions}

The main messages stemming from an analysis of the legal and regulatory framework and characteristics of the Colombian financial system are:

- The financial system had historically developed under a model of specialized 'vehicles' subject to severe restrictions on permissible activities

- Law 45/1990 converted the system into one of "multi-banking" (matrixsubsidiaries) and promoted the creation of financial conglomerates

- Legal reforms during the last 15 years have provided more flexibility but have not significantly changed the overall picture

- The current model is already de facto close to universal banking because of the presence of financial conglomerates, although it is more inefficient because their structures are not fully market-determined

- There has been a significant decline in the number of financial institutions over the last 10 years, which has been accompanied by an increase in the relative importance of institutional investors and capital markets

- The banking sector has mostly recovered from the 1999 financial crisis, although financial intermediation has been slow to pick up

- Two domestic mixed-activity economic groups (Grupo Aval and Grupo Sindicato) control the largest financial conglomerates and currently account for half of total bank assets

- Financial conglomerates are already leveraging many operational synergies, and this is expected to increase given the on-going consolidation process.

\section{The analytical approach developed in this paper has yielded the following recommendations:}

Table 16: Summary of Proposed Recommendations

\begin{tabular}{|c|c|l|l|}
\hline $\begin{array}{c}\text { Specific } \\
\text { Recommendations }\end{array}$ & $\begin{array}{c}\text { Allow banks to offer financial leasing services directly } \\
2\end{array}$ & $\begin{array}{l}\text { Introduce a specialized vehicle whose exclusive responsibility would be the management of } \\
\text { collective investment schemes }\end{array}$ \\
Allow banks to offer services currently provided by fiduciarias, with the exception of collective \\
investment schemes \\
AB
\end{tabular}


The motivations underlying the specific recommendations can be conceptually classified into three main types. These are:

- Exclusivity - the current legal and regulatory framework unnecessarily restricts a financial activity to a non-bank vehicle - for example, leasing (CFCs), fiduciary activities (fiduciaria) and investment banking (CFs and comisionistas) - or prohibits it altogether (e.g. acquisition financing)

- Fragmentation - the current legal and regulatory framework leads to the improper fragmentation of a financial activity across different vehicles that operate in distinct market segments and are subject to different regulations, such as the management of collective investment schemes (comisionistas and fiduciarias) and investment banking (CFs and comisionistas)

- Obsolescence - the historical rationale for the existence of certain vehicles is no longer valid given recent market developments, as is the case for CFs and sociedades de capitalización.

Even though the latter motivation (obsolescence) is probably less important than the first two motivations (exclusivity and fragmentation) in terms of priority and market impact, it is important to avoid market distortions that might arise from unnecessarily maintaining obsolete financial vehicles ${ }^{53}$.

Proposed recommendations would promote a more sound, transparent and market-oriented financial system, but their overall impact on the system's efficiency is likely to be moderate. Specific reforms would allow a more market-oriented financial structure, but are unlikely to lead to fundamental organizational changes within financial conglomerates that would significantly affect system-level efficiency. However, the reforms would encourage competition by smaller-sized players in niche segments (e.g. capital markets, asset management, fiduciarias) that rely on specialized vehicles with less onerous prudential requirements than banks, as well as by small banks that no longer need to maintain specialized vehicles to provide a broader range of financial services. General reforms might also contribute to greater operational efficiencies, but their overall impact is primarily on risk mitigation and would take longer to implement. Regulatory arbitrage, conflicts of interest and unfair competition would be significantly reduced, while legal certainty would be substantially improved. The effective supervision of financial conglomerates would enable better understanding of systemic risks that, in combination with more effective controls and with regulatory clarifications on permissible activities (including on the types of activities that can be shared/outsourced), would produce a more transparent, market-oriented and sound financial system.

\section{B. Implications for Supervision}

The proposed reforms would not change current supervisory priorities but would strengthen consolidated supervision of financial groups. The recent merger of

\footnotetext{
${ }^{53}$ For example, sociedades de capitalización are effectively competing with banks in financial savings intermediation and - in order to ensure a level playing field - should adjust their prudential and accounting framework accordingly.
} 
the two financial supervisors supports a more comprehensive and integrated outlook on financial regulation and supervision, which is needed in order to effectively address the dominant presence of financial conglomerates in the system. This is addressed both directly by the proposed reform on financial conglomerates, and indirectly by other proposed reforms (for example, prevention of potential conflicts of interest). Certain specific reforms add to the supervisory workload (e.g. investment banking and collective investment schemes), others potentially diminish it (e.g. elimination of CFs and sociedades de capitalización), while the effect is unclear for some others (e.g. changes to the financial system 'perimeter'). However, most reforms require new regulations and procedures that will take time to be developed, implemented and enforced. For example, if the proposed recommendations are adopted, it is likely that a review of minimum startup capital by type of financial vehicle and of minimum capital adequacy requirements by type of financial activity would be required.

\section{Implications for Competition}

The proposed reforms would likely make even more imperative the need for a clear antitrust policy governing the financial system. A comprehensive antitrust policy needs to be in place in light of existing economic realities and the on-going consolidation and privatization process, particularly as - given the proposed recommendations - the framework under which financial conglomerates operate is progressively liberalized. Clear coordination mechanisms (including the allocation of responsibilities) would need to be in place between the antitrust authorities and the financial supervisors in order to leverage the respective advantages of each one - namely, the broad experience of the former in competition issues and the specialized knowledge of the latter in financial system issues. A clear and transparent antitrust policy with objective criteria (for example, in terms of market definition, size, impact etc.) would also ensure that the 'rules of the game' are widely understood and respected.

\section{Proposed Roadmap}

A reform roadmap that includes these proposals needs to clearly distinguish between shorter- and longer-term policy measures in order to ensure a smooth transition path. It is beyond the scope of this document to propose a priori a detailed reform roadmap, but some high-level criteria on selecting short-term versus longer-term measures can be identified. This does not mean that longer-term reforms cannot or should not start immediately (nor does it mean that all reforms should start at the same time), but rather that they will by necessity take longer to reach fruition. The following criteria could be used for sequencing the proposed recommendations:

- Relative importance, which is a function of the benefits-risks trade-off and potential impact - for example, the introduction of collective investment schemes and the development of a full-fledged investment banking vehicle are arguably the two most important specific recommendations 
- Ease of implementation, which is a function of their complexity and the associated need for active consultation and involvement of all relevant parties - for example, allowing banks to directly offer financial leasing services is likely to be much easier to implement (but less important) than revising the hierarchy of the legal framework

- Potential for 'bundling', meaning that certain recommendations are related and work on them can progress concurrently so that they are included into a single reform package - for example, general recommendations $4 \mathrm{~A}$ and $4 \mathrm{~B}$ on financial conglomerates

- Inter-dependence, where the implementation of certain recommendations is conditional on others - for example, allowing banks to directly offer fiduciary activities and to undertake investment banking should not take place until the legal and regulatory framework on conflicts of interest is revised accordingly and effectively enforced.

The authorities will need to balance the relative importance that they attach on each of the aforementioned criteria in order to select an appropriately sequenced reform roadmap. 


\section{Bibliography}

Arbelaez M.A., Villegas F. and Salazar N. (October 2004), “El leasing en Colombia: Diagnóstico e impacto sobre la inversión y el crecimiento”, Fedesarrollo Cuaderno 13.

Clavijo S. (2000), “Towards multibanking in Colombia: From 'patchwork' to financial holdings”, Asobancaria convention paper.

International Monetary Fund (May 2005), “Colombia: Staff Report for the 2005 Article IV Consultation”, Country Report No. 05/154.

International Monetary Fund (August 2005), “Colombia: Financial System Stability Assessment Update”, Country Report No. 05/287.

International Organization of Securities Commissions (1996), "Report on Collective Investment Schemes in Emerging Markets", Report by the Emerging Markets Committee of IOSCO.

Stephanou C. (March 2005), "Supervision of Financial Conglomerates: The Case of Chile”, World Bank Policy Research Working Paper 3553.

World Bank (November 2005), "Implementation Completion Report for Second Programmatic Financial Sector Adjustment Loan to the Republic of Colombia”, Report No. 33764-CO. 